\title{
Research Paper \\ Hope for the Future, Attachment Relationships, and Emotional-Behavioral Problems in Child Labor
}

\section{Sana Simbar ${ }^{1}$, Abbas Ali Hosseinkhanzadeh ${ }^{* 2}$, Abbas Abolghasemi ${ }^{3}$}

1. M.A. Student of General Psychology, Faculty of Literature and Humanities, University of Guilan, Rasht, Iran 2. Associate Professor, Department of Psychology, Faculty of Literature and Humanities, University of Guilan, Rasht, Iran 3. Professor, Department of Psychology, Faculty of Literature and Humanities, University of Guilan, Rasht, Iran

Citation: Simbar S, Hosseinkhanzadeh AA, Abolghasemi A. Hope for the future, attachment relationships, and emotional-behavioral problems in child labor. Quarterly Journal of Child Mental Health. 2019; 6(3): 51-65.

\section{http://dx.doi.org/10.29252/jcmh.6.3.6}

\section{A R T I C L E I N F O}

\section{Keywords:}

Child labor, hope for the future, attachment relationships, emotional-behavioral problems

Received: 6 Feb 2018 Accepted: 29 Jul 2018 Available: 9 Nov 2019

\section{A B S T R A C T}

Background and Purpose: Child labor is an important global issue, because it affects the physical, psychological, and moral well-being of children. Working children are exposed to physical hazards, stress, and psychosocial problems. Therefore, the present study aimed to compare future hope, attachment relationships, and emotional-behavioral problems in working children and their peers. Method: It was a descriptive study with an ex-post facto research design. The sample included fifty 10-12 year old children from Rasht's Child Labor Institute and fifty peers from an adjacent school who were selected by convenience method based on inclusion criteria. To collect data, Children's Hope Scale (Schneider et al., 1997), Kinship Center Attachment Questionnaire (Halpern \& Copenberg, 2006), and Behavioral Questionnaire for Parents and Teachers (Rutter, 1975) were administered to groups. Independent t-test and multivariate analysis of variance were used for data analysis.

Results: The results of the present study showed that the total index of hope in the child labor group was significantly lower than the peer group $(\mathrm{P}<0.002)$, and the total score of emotional-behavioral problems from the parents' point of view $(\mathrm{P}<0.003)$, and the total score of emotional-behavioral problems from the teacher' point of view $(\mathrm{P}<0.001)$ were significantly higher in the child labor group than other peers. The results also showed that, the mean score of all subscales of the attachment questionnaire, except for emotional response, was significantly lower in child labor than other peers $(\mathrm{P}<0.001)$ and the mean score of all subscales of emotional-behavioral problems from the teacher' point of view, was significantly higher in child labor group compared to the other group $(\mathrm{P}<0.002)$. Conclusion: According to the results of the present study, it can be concluded that due to the severe living conditions, the working children do not receive the necessary and adequate support from their families and parents. This, in turn, leads to the lack of secure attachment with parents and lowers the level of hope for future in these children. On the other hand, their working environment is full of physical and sexual misbehaviors which may develop emotional-behavioral problems in them.

\footnotetext{
* Corresponding author: Abbas Ali Hosseinkhanzadeh, Associate Professor, Department of Psychology, Faculty of Literature and Humanities, University of Guilan, Rasht, Iran.

E-mail addresses: Khanzadehabbas@guilan.ac.ir
}

2476-5740/ (C) 2019 The Authors. This is an open access article under the CC BY-NC-ND license (https://creativecommons.org/licenses/by-nc-nd/3.0/). 


\section{اميد به آينده، روابط دلبستكى، و مشكلات هيجانى - رفتارى در كود كان كار \\ ثنا سيمبر '، عباسعلى حسين خانزاده*” r عباس ابوالقاسمى}

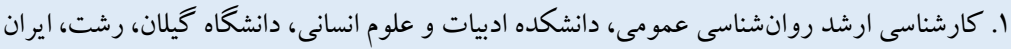

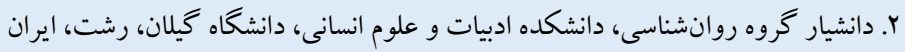

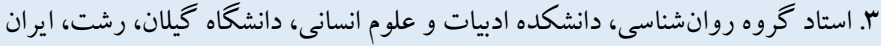

جكبين

زمينه و هدف: كار كود كان يكك موضـوع مهم جهانى اســت، زيرا بر بهزيسـتى جسـمى، روانى، و اخلاقى كود كان تأثير مى گذارد و كود كان شـاغل در معرض خطرات جسـمى، تنش، و مشكلات روانى -اجتماعى قرار دارند. بدين ترتيب يثزوهش حاضر با هدف مقايسه اميد به آينده، روابط دلبستكى، و مشكلات هيجانى - رفتارى در كود كان كار با ساير همسالان انجام شد.

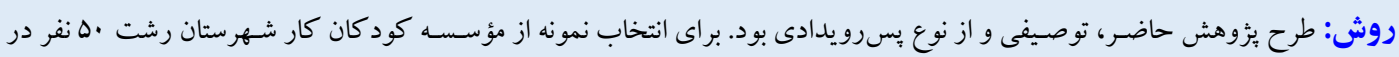

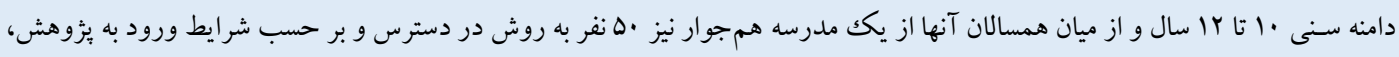

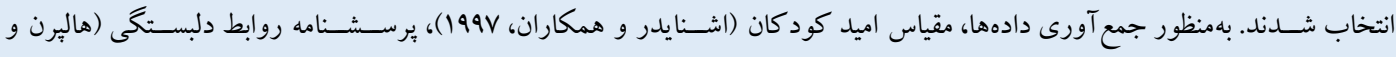

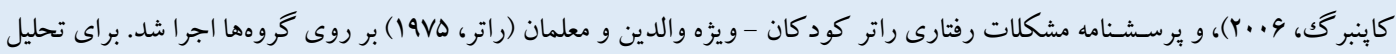
دادهها نيز از آزمون t مستقل و تحليل واريانس جندمتغيره استفاده شد. يافته ها: نتايج حاصل از يثوهش حاضر نشان داد كه نمره شاخص كلى اميد به آينده در گروه كود كان كار نسبت به ساير همسالان بهطور

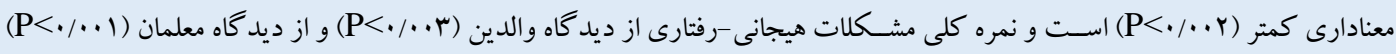
در گروه كود كان كار نسبت به ساير همسالان، بهطور معنادارى بيشتر است. همجنين نتايج نشان داد كه ميانگين نمره تمامى خردهمقياس هاى

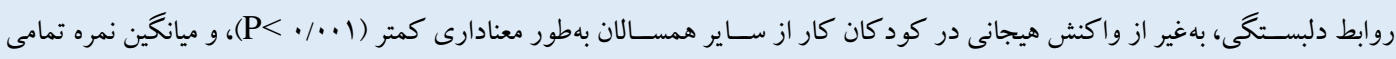

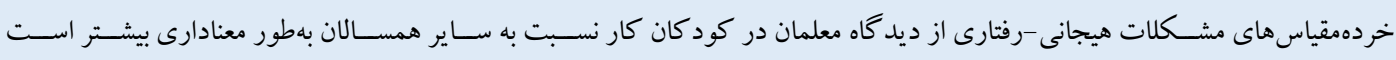

$(\mathrm{P}<\cdot / \cdots r)$

نتيجه كيرى: بر اساس نتايج حاصل از ئزوهش حاضر، مى توان كفت كه شرايط سخت زندگى كود كان كار باعث مىشود تا حمايت للازم و كافى را از خانو اده و والدين حامى دريافت نكنند و اين خلأ، موجب عدم شكل كيرى دلبستخى ايمن با والدين شده و ميزان اميد به آينده را در آنها كاهش مىدهد. از سـويى ديخر، محيط كار براى كود كان ســشـار از بدرفتارىهاى جسـمى و جنسـى اسـت كه موجب بروز مشكلات هيجانى -رفتارى در آنها مىشود.
مشخصات مقاله

كليدوازهها:

كودك كار، اميد به آينده، روابط دلبستخى، مشكلات هيجانى - رفتارى

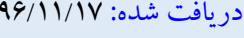
يذير فته شده: V/ منتشر شده: جئ

* نويسنده مسئول: عباسعلى حسين خانز اده، دانشيار گروه روانشناسى، دانشكده ادبيات و علوم انسانى، دانشكاه كيلان، رشت، ايران.

Khanzadehabbas@guilan.ac.ir رايانامه

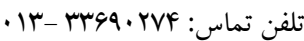


يرداختند، حاكى از آن بود كه يكى از بنج تصويب كننده قانون محافظت

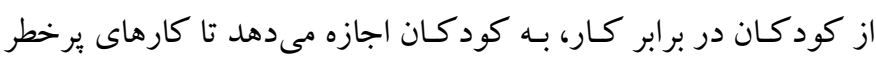

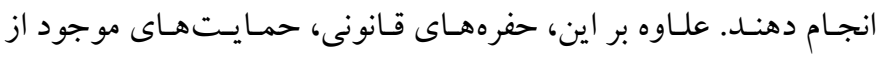

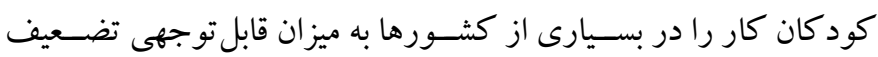

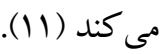
اشـنايدر " (1991)، ملقب به سـلطان اميد، براى نخسـتين بار نظريهاى

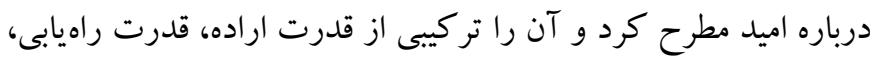

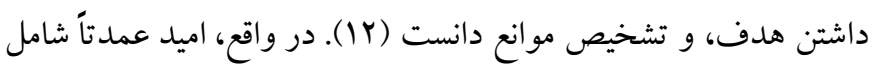
دركك مخاطب از سـهم شـحسى خود براى رسيدن به اهداف مورد نظر

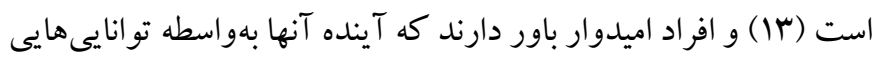
كـه دارنـد، موفقيت آميز خواهد بود (f) (I). وجود اميد در تحول ســالم كود كك از اهميت باليى برخوردار است و احساس امنيت باعث به وجود ميرد

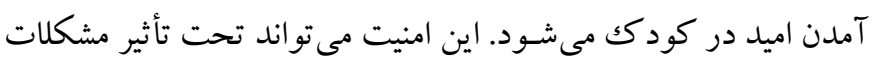

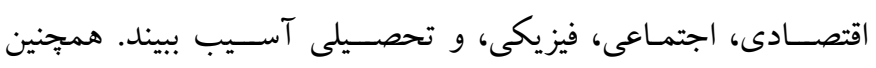

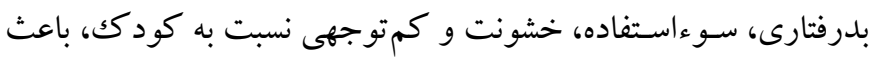

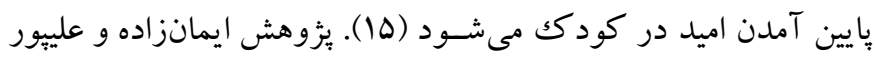
نيز نشـان داد كه كود كان كار در معرض انواع احسـاس تنهايى هستند و ودئ

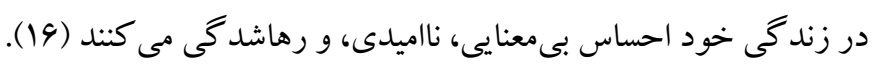

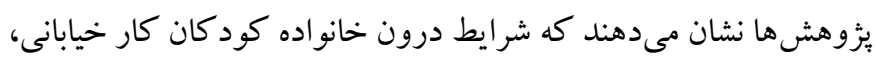
شـامل رفتار انحر افى درون خانواده، تغيير سـاختار خانو اده، روابط درون

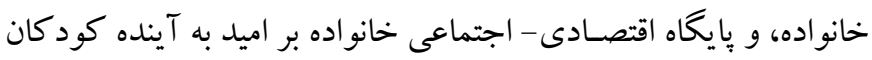

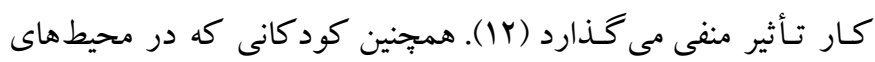

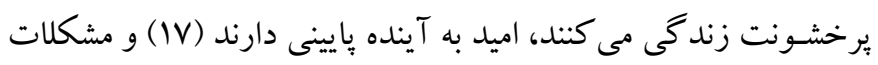
اقتصادى و عدم دسترسى به تحصيل، اميد به آينده را در اين كود كان از

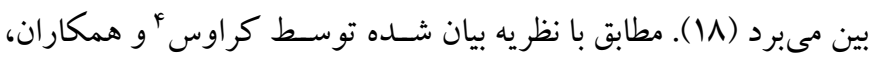

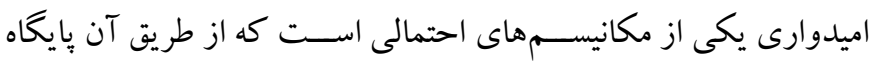

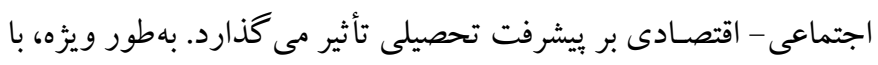

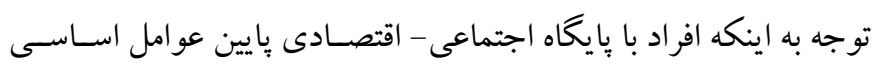

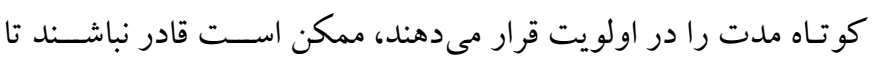
بهطور مؤثر و كار آمد بر روى اهداف مربوط به آينده تمركز كنند (19).
مقلدمه

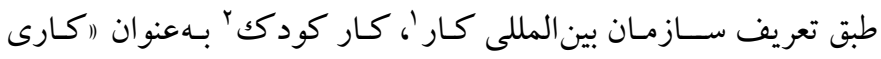

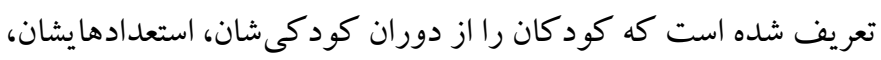
و شـأن و منزلتشـان محروم مى كند و براى تحول جسـمانى و روانى آنها

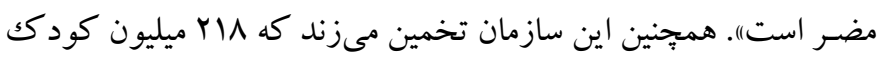

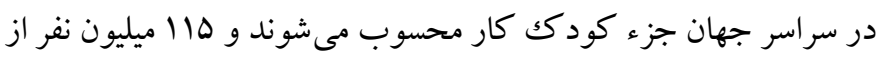

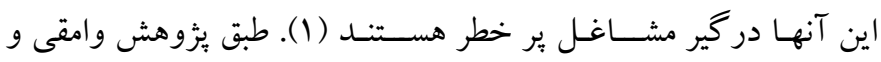

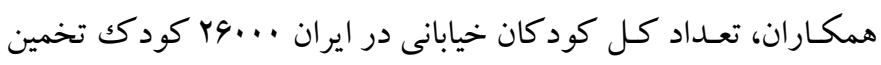
زده شـده اسـت (Y). كود كان كار بخشى از جامعه انسانى هستند كه زير ها سال سن دارند و در حالى كه دوره تحول جسمى و روانشناختى آنها

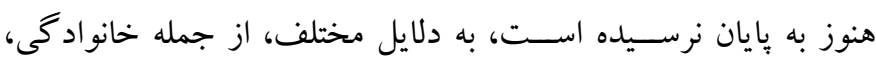

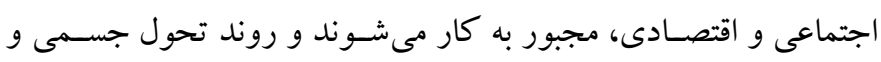

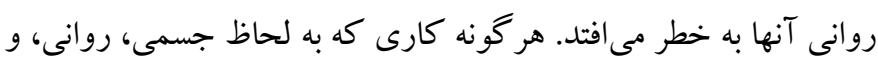

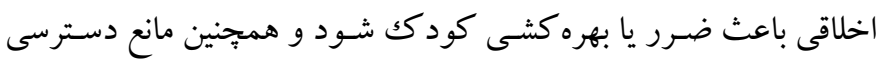

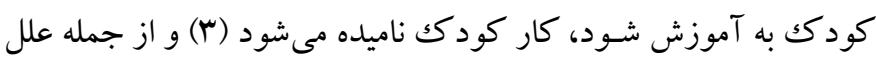

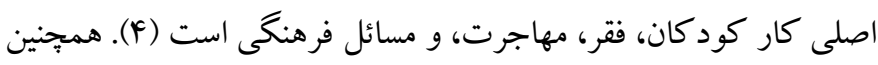

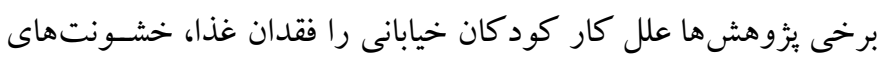

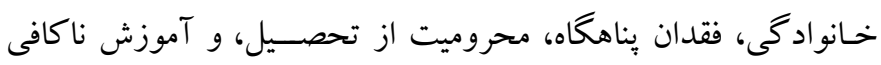

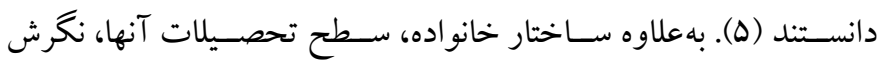
خـانو اده، و كماهميـت بودن تحصـيل كودكك براى خانو اده، عامل مهم

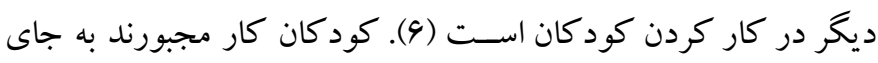

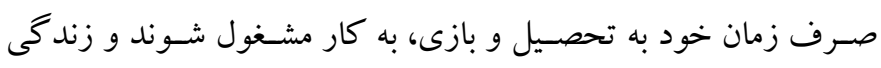

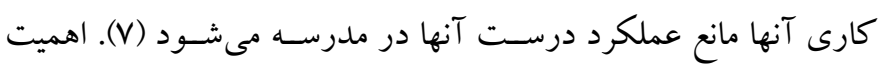

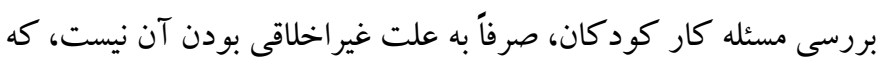

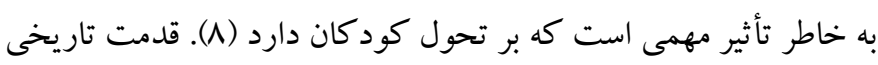

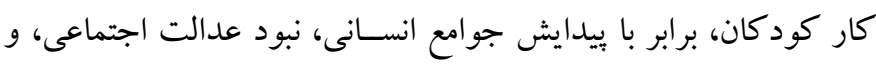

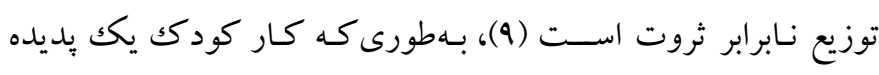

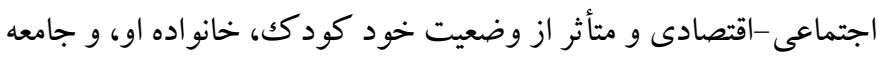

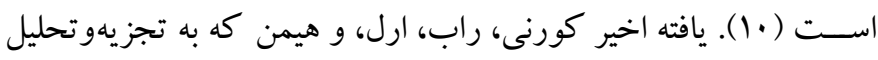

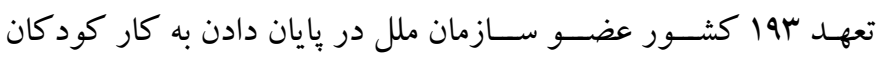


مشكلات تحصيلى بيشترى را نشان مىدهند ( آr). بادمجى، كارادايى، و دىزولو تا در مطالعه خود نتيجه گرفتند كه توسعه روابط دلبستخكى ايمن بـا يكك فرد معتمد، اتخاذ شــيوه كود ككمحور، و و ايجاد يكك محيط امن اجتماعى كه با حمايت همسالان ايجاد شود، ظرفيت كود كان و نوجوانان را براى تنظيم احسـاسـات، احساس حرمت خود، تاب آورى، و تمايل به

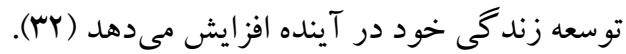

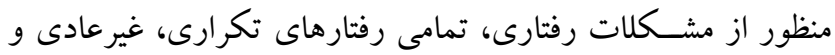

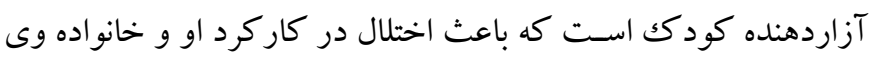

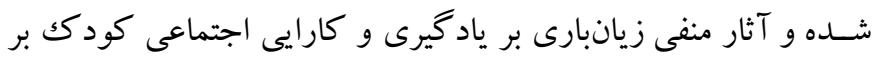

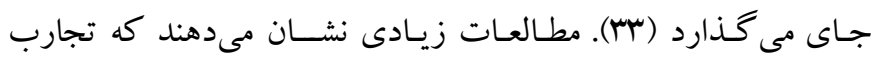
تنش آور كود كىى، خطر ابتلا به اختلالهاى مغزى و مشـكلات رفتارى را

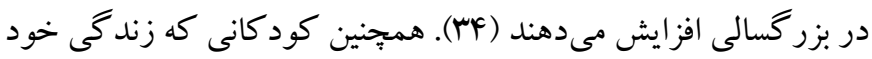

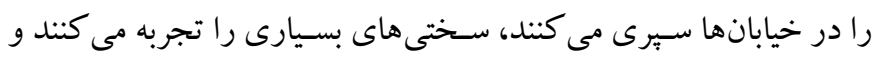
شيوع مشكلات هيجانى -رفتارى در اين كود كان بسيار بالاتر است (هـ). طبق شــواهد، كود كان كار قربانى آزار جنسـى، نسـبت بـ به كود كان

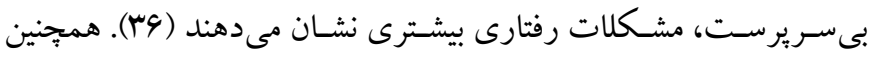

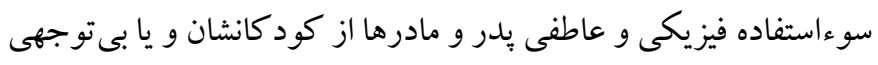

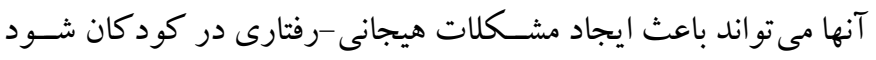

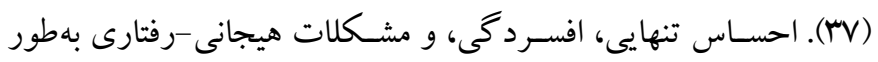
قابل توجهى در كود كان كار بيشـتر از سـاير كود كان مشـاهده مى شـود

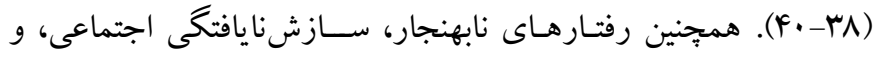
اختلال نارسايى توجه در اين كود كان بهطور معنادارى بيشتر است (1)

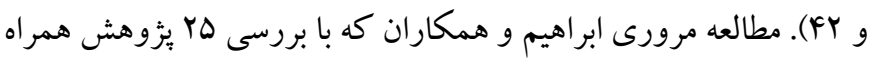

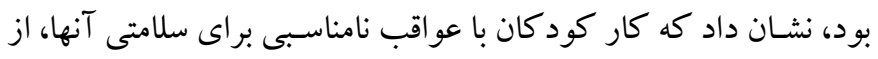
جمله سـو ت تغذيه و شيوع بالاتر بيمارى هاى عفونى، همراه است. همجنين

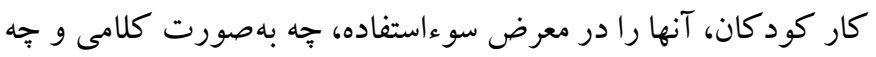
بهصورت جسمى يا جنسى، قرار مى دهد كه در نهايت منجر به اختلالات

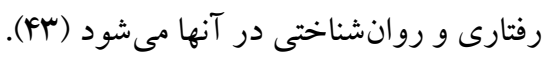

با توجه به نتايج ئزوهشهاى بررسى شده، شاهد هستيم كه در سراسر جهان، بهويزه در كشـورهاى عقبمانده صسنعتى، كود كان به علت فقر و

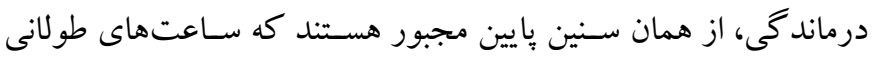

اين نتايج بهطور ضـمنى مى تواند گوياى اين حقيقت باشـد كه كود كان كار با توجه به يايخاه اجتماعى - اقتصـادى يايين، هم اميد كمى به به آينده دارند و هم اين اميدوارى پايين به افت بيشرفت تحصيلى و تركك تحصيل در آنها منجر مىشود. بالبى' (1999) معتقد است نياز دلبستخى، يكك نياز اساسى براى تحول

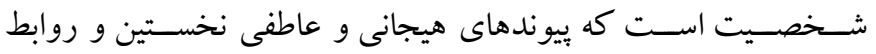

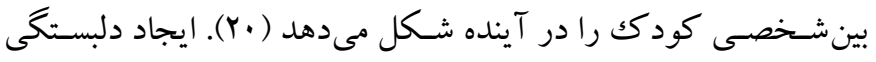
براى تحول شـناختى و عاطفى كودكك ضـرورى اسـت و خانو اده، زمينه

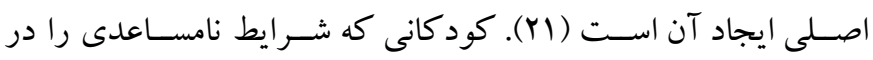

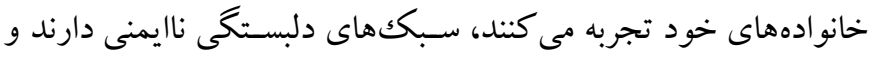

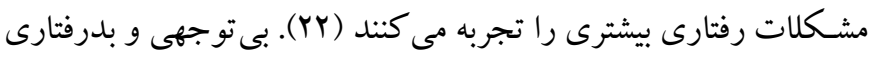
نسبت به كود كان و سوءاستفاده از آنها، بهصورت مستقيم و غير فيرمستقيم باعث ايجاد سبك دلبستكى نايمن و مشكلات روانشناختى در كو دكان

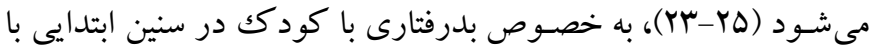

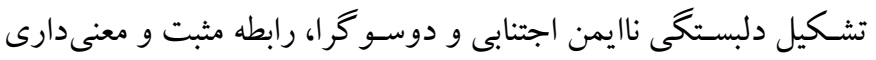

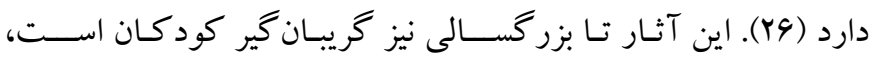

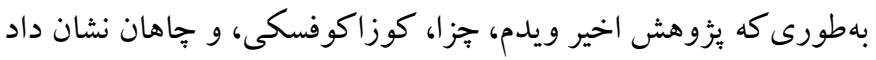

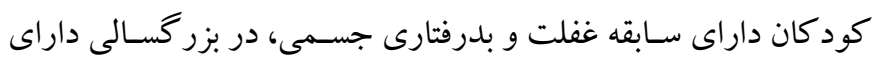

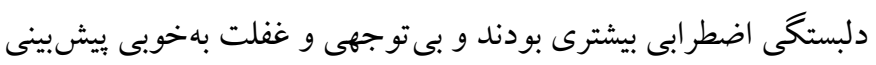

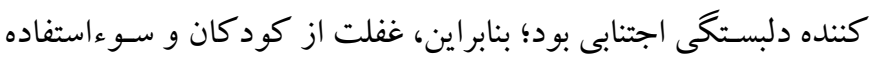

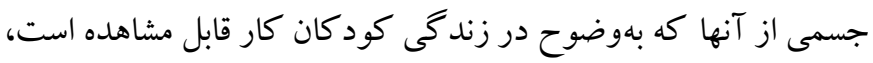

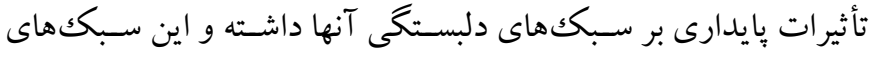

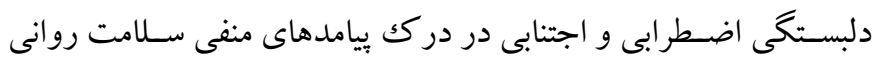
ناشسى از سـوءاسـتفاده در كود كى حتى تا ·r ســال بعد نيز نقش دارند

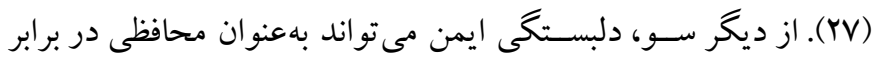

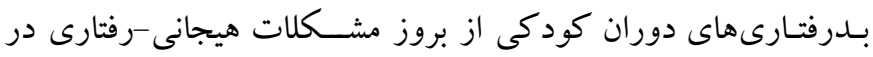

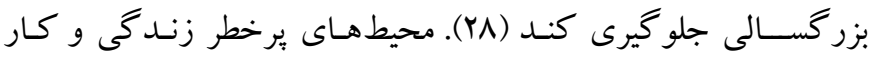

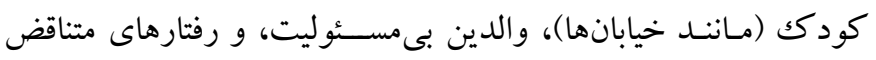

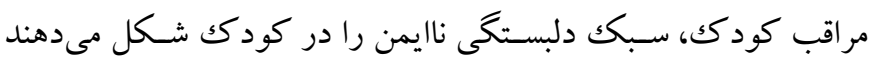

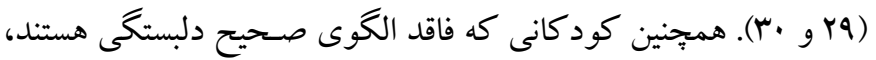

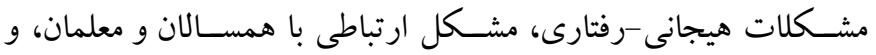




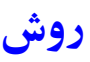
الف) طرح يزووهش و شـر كت كنند كان: طرح يزوهش توصيفى و از

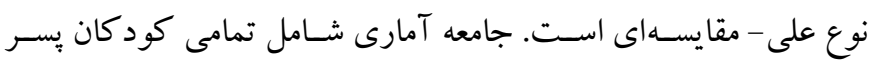

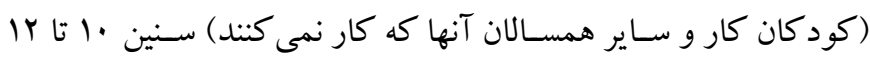

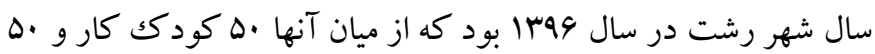

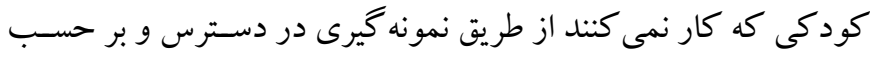

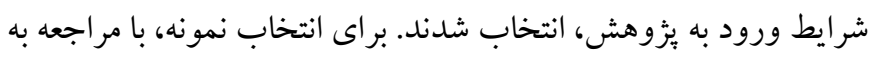

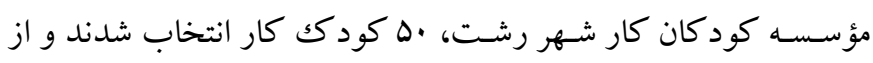

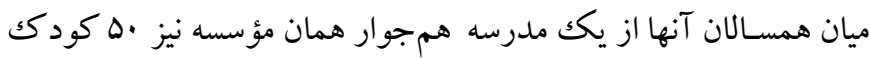

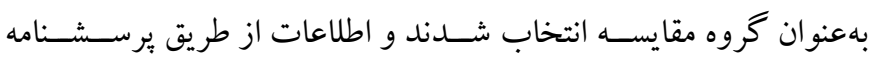

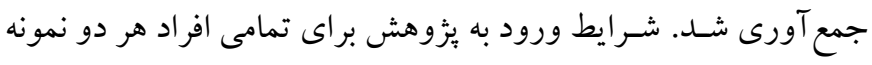

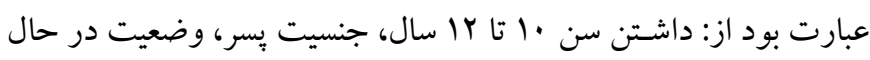

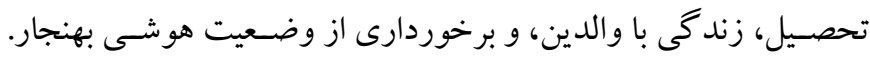

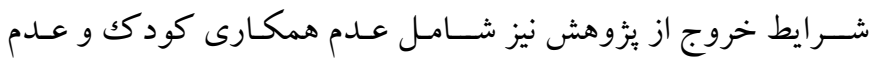
رضايت والدين بود.

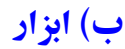
1. مقياس /ميد كودكان': اين مقياس توسط اشنايدر و همكاران (IA9V) طر احى شـــه و و عبارت دارد كه تفكر عاملى، تفكر راهبردى، و و اميد

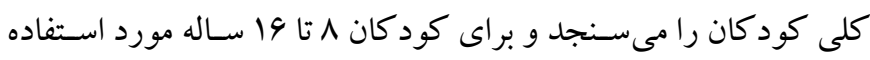

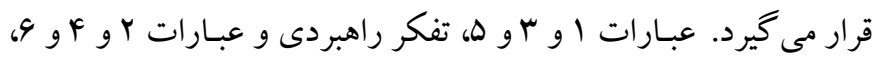

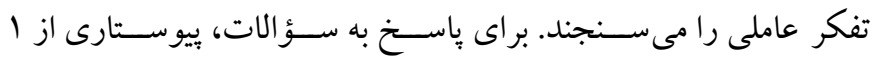

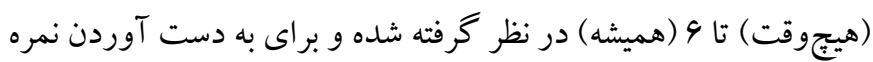

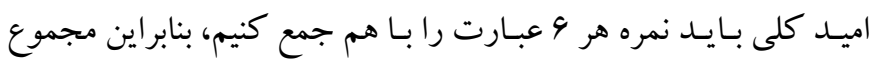

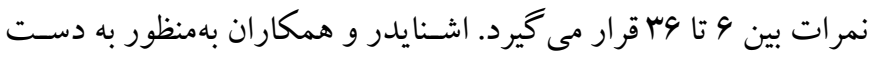

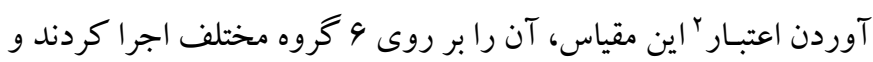

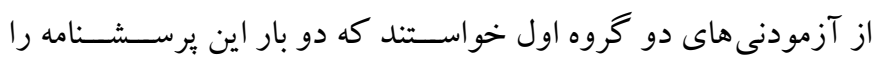
تكميل كنند كه در نتيجه ضـريب باز آزمايى آن در حد بالايى به دست آنست

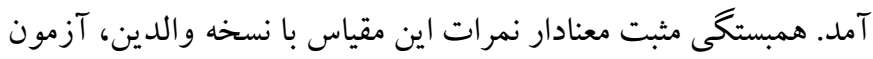

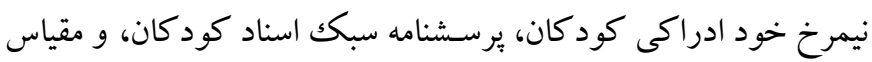

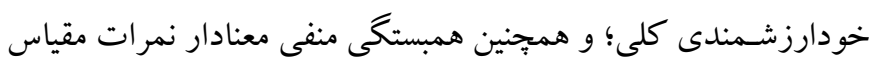

تحت شـرايط سخت جسهمى و روانى براى كمكك به خانواده خود كار

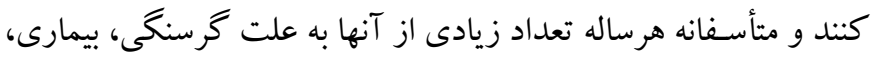

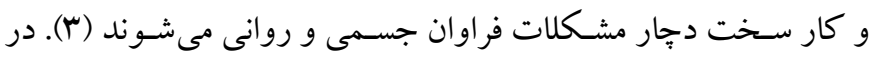

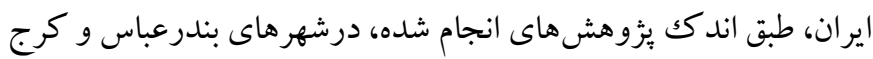

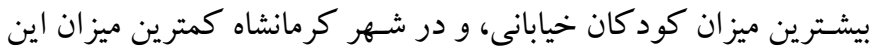

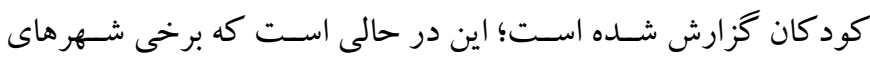

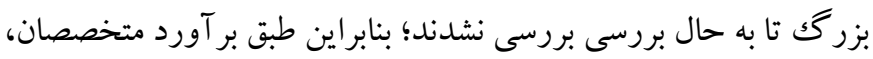

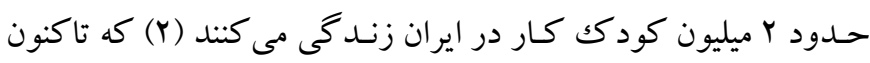

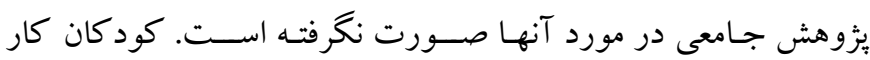

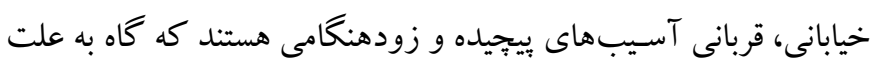
داشتن والدين نالايق و عدم آموزش و تربيت للازم به تجربه اين مشكلات التهات

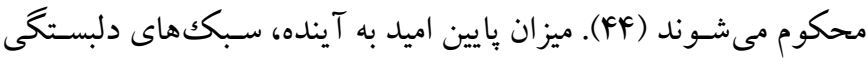

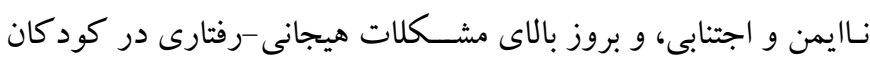

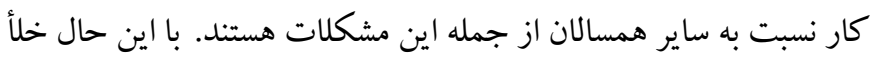

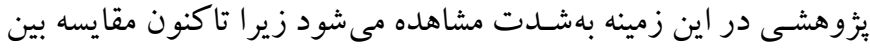

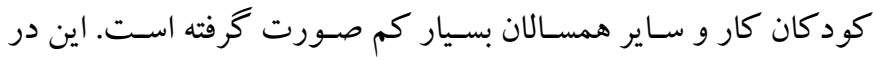

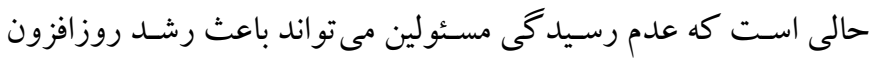

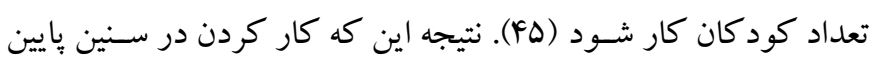

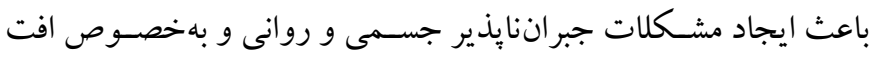
تحصيلى شـديد در كود كان خواهد شد و اثرات منفى آن بر كل جان جامعه

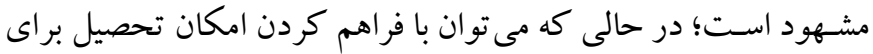

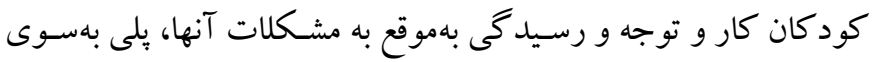

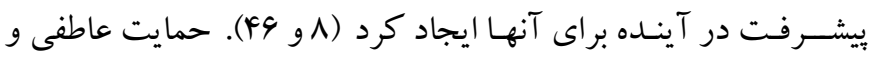
تحصسيلى خانوادهها بهمنظور تحول ذهنى و روانى كودك و و جلو كيرى آنسي

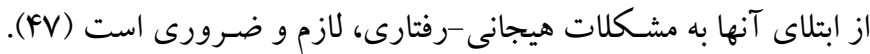

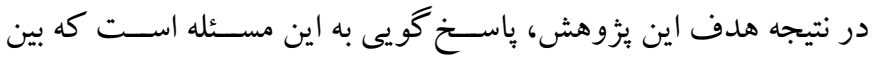

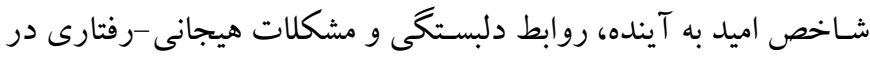
كود كان كار و ساير همسالان خه تفاوتى وجود دارد؟ 
ينج خردهمقياس يرخاشــرى و فزون كنشىى، اضطر اب و افسـردگى،

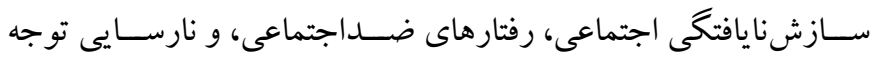

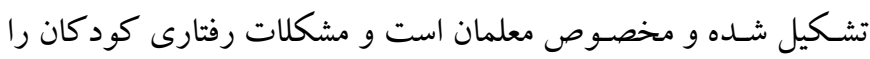

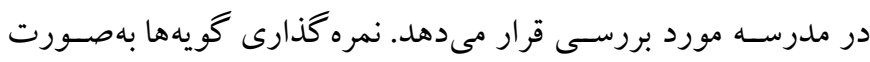

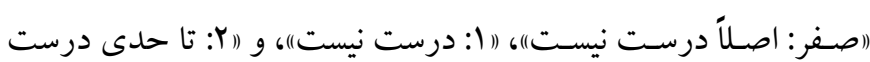
اسـت) انجام مىشـود و دامنه نمرهها بين صـفر تا وب اسـت كه نمره با نقطه برش محســوب مىشــود و كود كانى كه نمره لا يا بالاتر بـيرند،

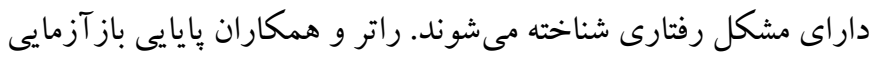

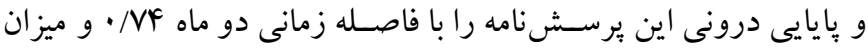

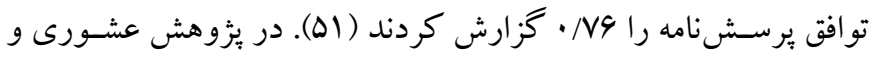

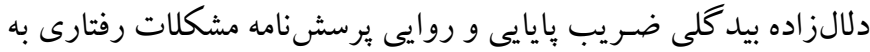

$$
\text { ترتيب •V/ • و VA/ • گزارش شد (OY). }
$$

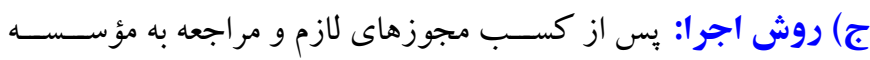
كود كان كار در رشـت، اطلاعاتى كلى در مورد كود كان به دست بـ آمد. سـس •ها نفر از كود كان كار مورد نظر يزوهش به شـيوه در دسـترس

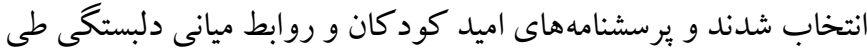

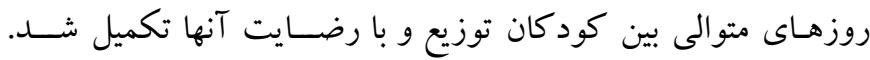

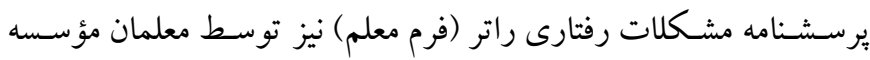
تكميل شـدند. در اجراى برسـشنامههاى والدين با مشكل اساسى روبهرو بوديم، زيرا بيشتر اين والدين بىسواد بودند. به همين دليل طى جلسهاى، يرسـشـنامهها با همكارى كود كان و مسـئولان مؤسسه از طريق برسش و و

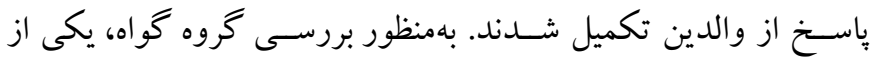

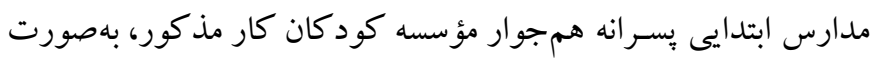

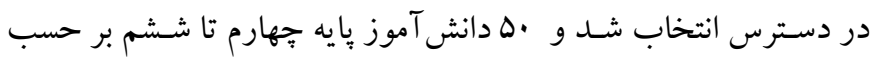
شـرايط ورود به بزوهش از اين مدرسـه انتخاب شــند. با مراجعه به اين كلاسها و با كمكك معلم هر كلاس، يرسـشـنامههاى مربوط به كود كان

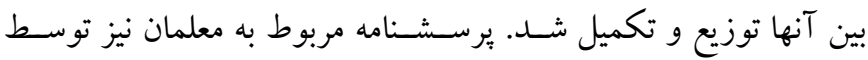

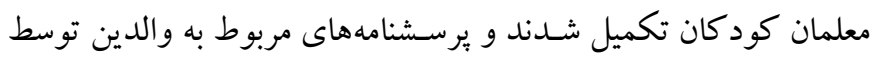

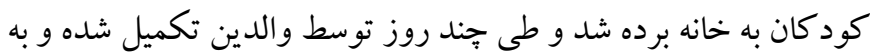

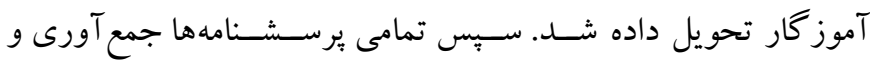

اميد كود كان با نمرات آزمون افسـردگى كود كان، نشـاندهنده روايى' همخراى مقيـاس اميـد كودكـان اســت. همجِنين نمرات اين مقيـاس بـا

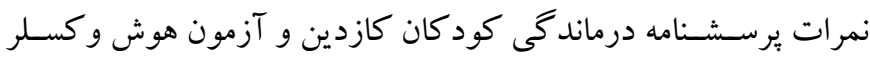

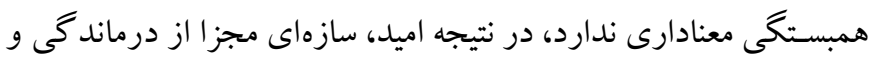
هوش اسـت كه نشــاندهنده روايى افتراقى اين مقياس اســت. بهعلاوه همبسـتخى معنادار (ه/•>•P) اين مقياس با آزمون مهارتهاى ابتدايى آيوا، نشـاندهنده روايى بيشبين اين آزمون است (FN). در يثزوهشى كه

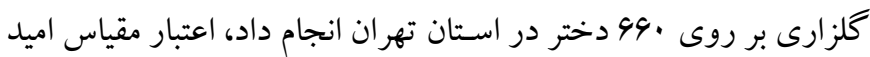
اشـنايدر با روش همسـانى درونى بررسى شـــ و ضريب آلفاى كرونباخ ه9/1 • به دست آمد (به نقل از Fq).

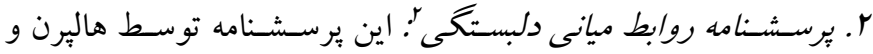

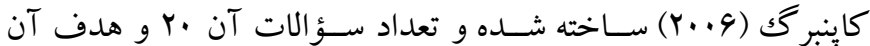
سنجش دلبستگى كود كان در دوره ميانى (قبل از دبستان و دبستان) و در ابعاد مختلف (تكامل انطباقى مثبت، واكنش هيجانى، رفتارهاى منفى،

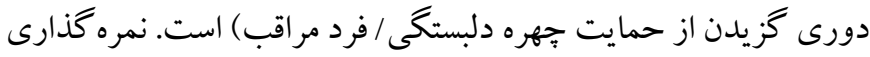

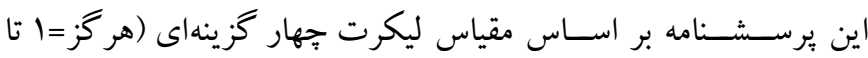

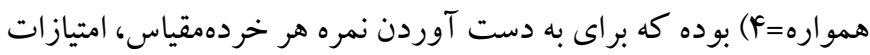
سؤسألات مربوط بـه همـان خردهمقيـاس را جمع مى كنيم. اعتبـار اين

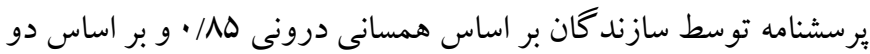

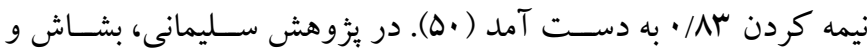

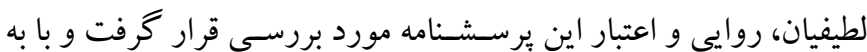

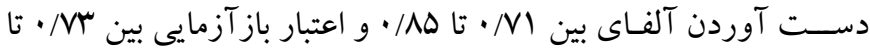

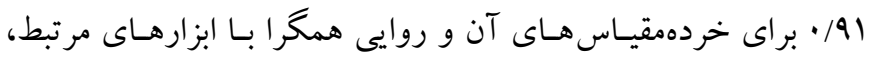

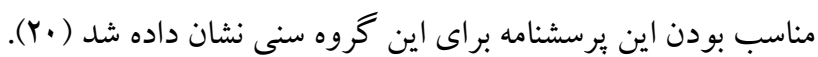
". برسـشـنامه مشـكلات رفتارى راتر كودكان ويثه والدين و معلمان". نسخه اوليه اين يرسشنامه در سال 199V توسط مايكل راتر تهيه شد و در

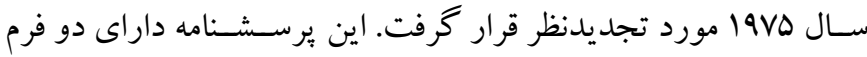
والـدين (فرم الف) و معلم (فرم ب) اســت كـه فرم الف از ه ل اعبـارت

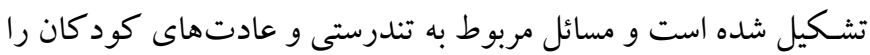

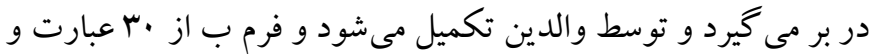


جدول نتايج آزمون كالمو گروف-اسـميرنف (K-S Z) براى بررسـى تجزيسهو تحليـل دادهها با آزمون تى و تحليل واريانس جندمتغيرى انجام نرمال بودن متغيرهاى يزووهش گز ارش شدهاند. طبق اين جدول، آماره Z

آزمون كالمو گروف-اســميرنف براى تمامى متغيرهاى يزٔوهش در دو

كروه كود كان كار و ساير همسالان معنادار نيست؛ بنابر اين مىتوان نتيجه كرفت كه توزيع متغيرها نرمال است و مىتوان از آزمونهاى بارامتريك مانند تحليل واريانس جندمتغيرى و آزمون t استفاده كرد.

يافتهها در جدول ا شـاخصهاى توصسيفى متغيرهاى يزٔوهش اعم از ميانگين و انحر اف معيار به تفكيك كروهها گز ارش شـده اسـت. همجِنين در اين جدول ا: شاخصهاى توصيفى متغير هاى ثئوهش به تفكيكى كروه كود كان كار و ساير همسالان (تعداد: . ․ نفر)

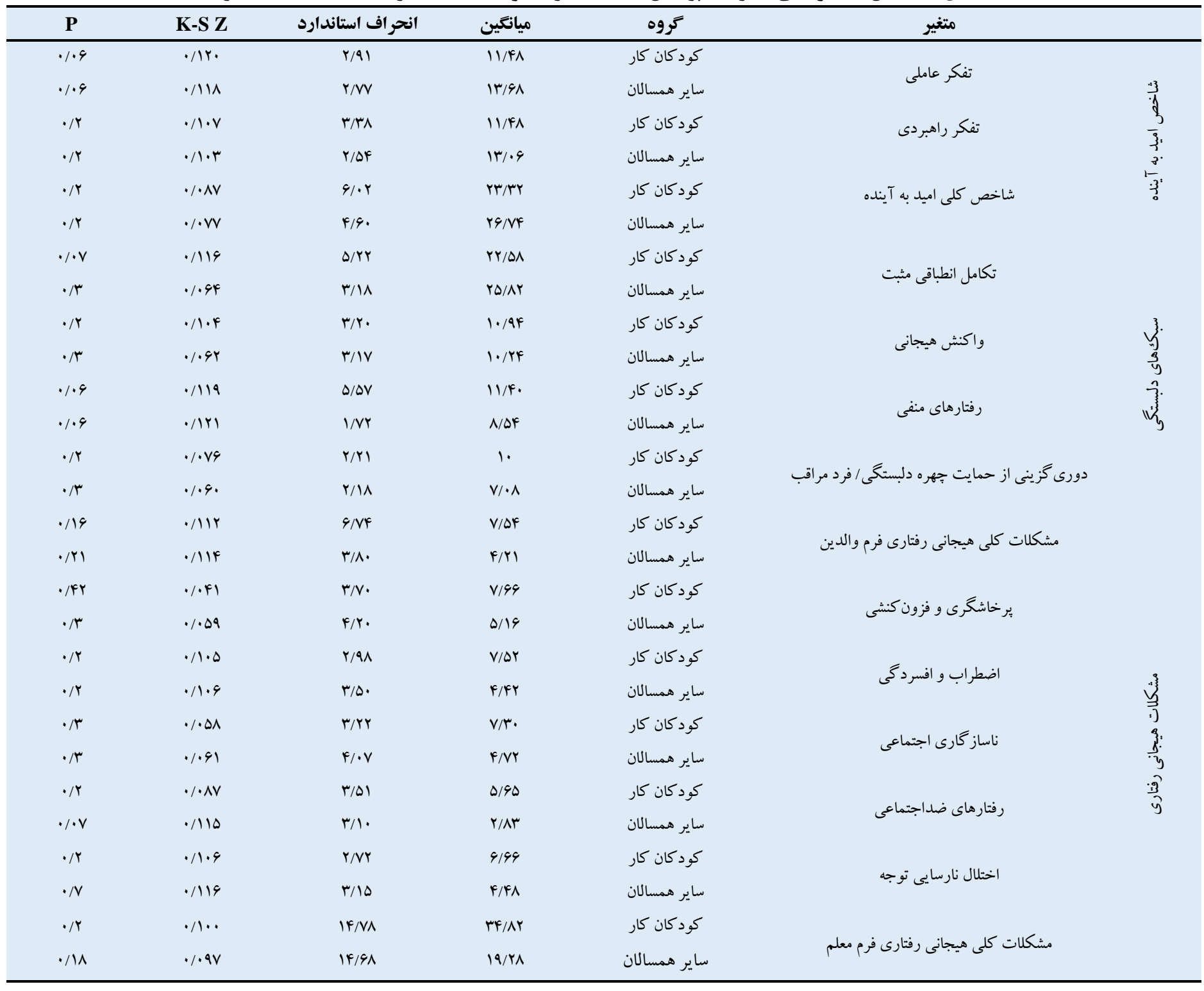

نيز نمره كلى مشكلات هيجانى -رفتارى از ديد معلم از آزمون t دو نمونه جهت بررسى تفاوت كود كان كار و ساير همسالان در متغيرهاى نمره مسـتقل اسـتفاده شـد. قبل از اجراى اين آزمون، ييشفرضهاى آن مورد كلى اميد به آينده، نمره كلى مشكلات هيجانى -رفتارى از ديد والدين، و 
نشــان مىدهد كه واريانس خطاى اين متغيرها در دو گروه همخن (P>

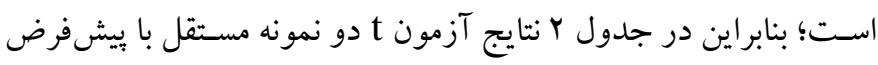

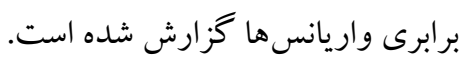

بررسـى و تأييـد قرار گرفت. نتايج آزمون لوين براى بررسـى همخنى

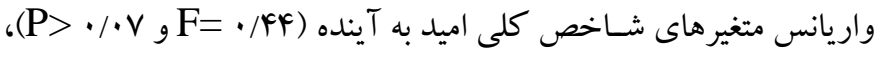
مشـكلات كلى هيجانى -رفتارى از ديد والدين ( F و نيز مشـكلـات كلى هيجـانى -رفتـارى از ديد معلم (F= F/VV) و 9.

جدول r: شاخصهاى توصيفى كروهها در متغيرهاى شاخص كلى اميد به آينده، مشكلات كلى هيجانى-رفتارى از ديد والدين و مشكلات كلى هيجانى_رفتارى از ديدكاه

\begin{tabular}{|c|c|c|c|c|c|c|c|}
\hline \multicolumn{8}{|c|}{ معلم } \\
\hline سطح معنادارى & درجه آزادى & t to & تفاوت ميانكين & انحراف معيار & ميانكين & كروه & متغير \\
\hline \multirow{2}{*}{$\% r$} & \multirow{2}{*}{91} & \multirow[t]{2}{*}{$-r / 19 r$} & \multirow[t]{2}{*}{$-r / k r$} & $9 / \cdot r$ & rr/Mr & كود كان كار & \multirow{2}{*}{ اميد به آينده } \\
\hline & & & & F/9. & rq/VF & 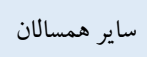 & \\
\hline \multirow{2}{*}{$\% r$} & \multirow{2}{*}{91} & r/Fr & \multirow{2}{*}{ r } & G/VQ & V/DF & كود كان كار & \multirow{2}{*}{ مشكلات هيجانى-رفتارى از ديد والدين } \\
\hline & & & & $r / \Lambda$. & $F / Y)$ & ساير همسالان & \\
\hline \multirow{2}{*}{.$/ .1$} & \multirow{2}{*}{91} & $F / Y$ & \multirow{2}{*}{$|r / Y|$} & $\mid f / v A$ & MF/AY & كود كان كار & \multirow{2}{*}{ مشكلات هيجانى -رفتارى از ديد معلم } \\
\hline & & & & $91 / 01$ & $r \mid / 91$ & ساير همسالان & \\
\hline
\end{tabular}

كلى هيجانى -رفتارى از ديد معلم در گروه كود كان كار بهطور معنادارى

$$
\text { بيشتر است (P</.. (P). }
$$

براى مقايسـه و بررسسى خردهمؤلفه هاى اميد به آينده (تفكر عاملى،

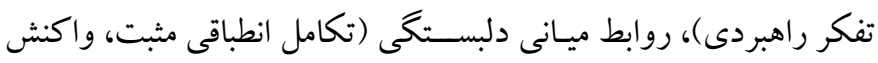

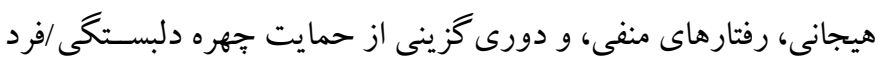

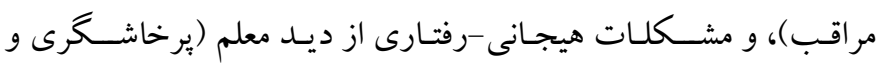

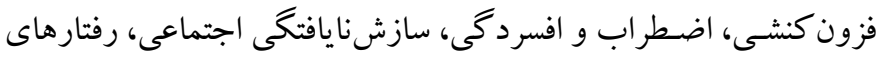

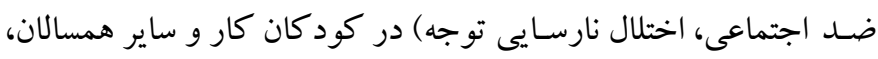

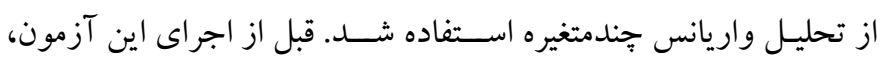

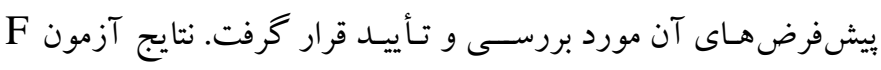
لوين براى بررسـى همخنى واريانس هاى خطاى متغيرهاى وابســـه در

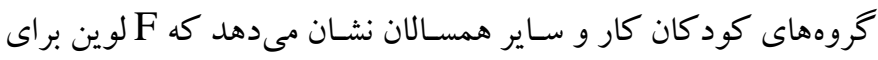

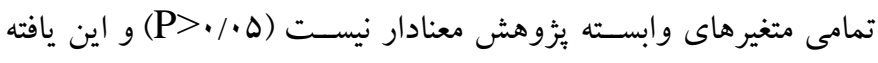
نشان مىدهد كه در دو گروه، فرض همخنى واريانسهاى خهاى خطاى متغيرها

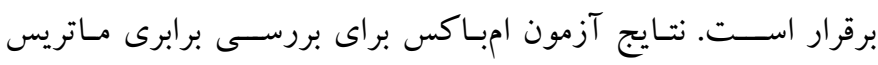

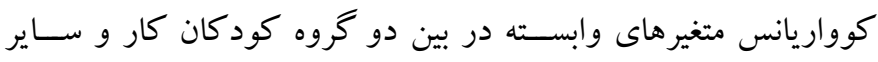

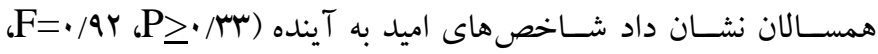
BoxM=人/rF

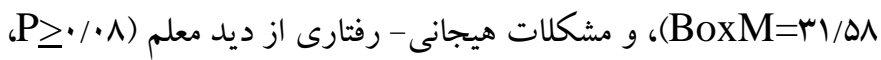

بـا توجـه به جدول r، در متغير شــاخص كلى اميد به آينده ميانگين

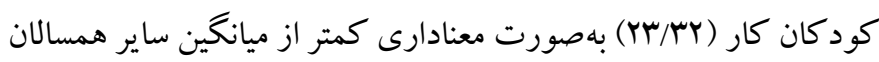
(Y\&/VF) بين ميانگين نمره شـاخص كلى اميد به آينده در دو گروه تفاوت معنادار وجود دارد، بهطورى كه شــاخص كلى اميد به آينده در گروه كود كان

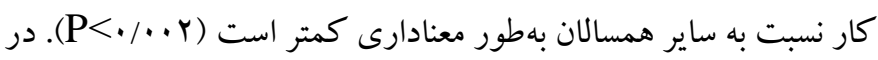
متغير نمره كلى مشــكلـات هيجـانى -رفتـارى از ديـــ والـدين، ميـانگين كود كان كار (V/DF) بهصورت معنادارى بيشتر از ميانگين ساير همسالان

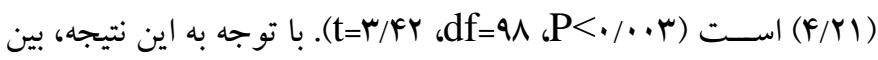
ميانگين نمره مشـكلات كلى هيجانى -رفتارى از ديد والدين در دو گروه تفاوت معنادار وجود دارد، بهطورى كه مشكلات كلى هيجانى -رفتارى از

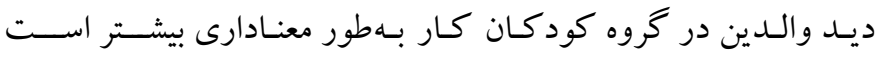

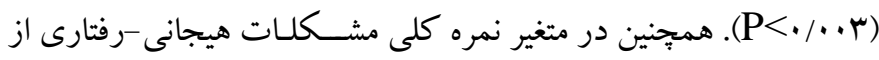
ديـد معلم نيز ميـانگين كود كان كار (MF/AY) بهطور معنادارى بيشـتر از

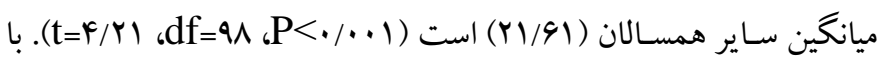
توجه به اين نتايج، بين ميانگين نمره مشـكلات كلى هيجانى-رفتارى از

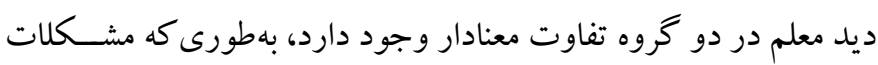


Filk’s Lambda=•/^९)، F=V/^•^

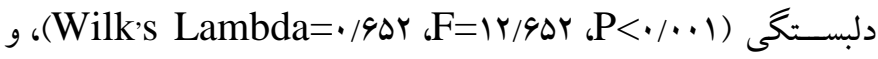

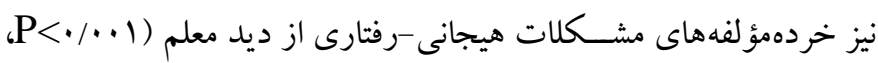

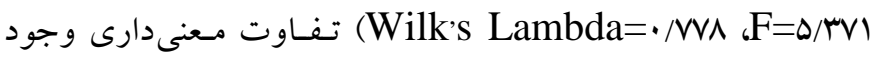
دارد. نتايج بررسى اينكه گروه كود كان كار و سـاير همسـالان در كدام

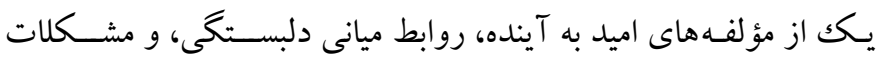

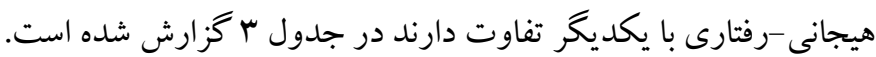

(BoxM=r9/VV، در دو گروه برابر اســت.. نتـايج آزمون خىدو بارتلت براى بررسى كرويت يا معنىدارى رابطه شاخصهاى اميد بـه آينـده (

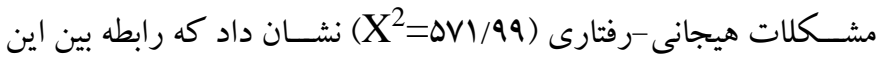

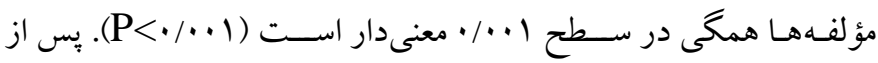
بررسـى بيشفرض هاى تحليل واريانس تجندمتغيرى، نتايج آزمون نشـان

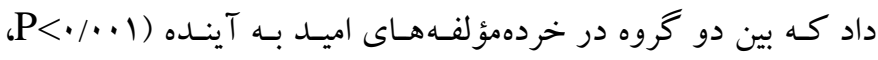

جدول "ا: نتايج تحليل واريانس جندمتغيره نمرات شاخصهاى اميد به آينده، روابط ميانى دلبستىى، و مشكلات هيجانى-رفتارى در دو كروه كودكان كار و ساير همسالان

\begin{tabular}{|c|c|c|c|c|c|c|}
\hline اندازه اثر & $\mathbf{P}$ & $\mathbf{F}$ & $\begin{array}{c}\text { ميانكين مجذورات } \\
\text { خطا }\end{array}$ & Df & $\begin{array}{c}\text { ميانكين مجذورات } \\
\text { كروه }\end{array}$ & مؤلفه \\
\hline ( &.$\cdot \cdot 1$ & $10 / \cdot Y r$ & $\Lambda / \cdot \Delta \Delta$ & 1 & $|r|$ & تفكر عاملى \\
\hline$\cdot / \cdot 41$ &.$/ F F$ & $f / 190$ & N/QMF & 1 & $r V / r i$. & تفكر راهبردى \\
\hline ./Irs &.$\cdot \cdot 1$ & $\mid \psi / \cdot \Delta \lambda$ & $1 N / 999$ & 1 & rGY/FY. & تكامل انطباقى مثبت \\
\hline.$/ \cdot 1 r$ & $\cdot / T V F$ & $1 / r \cdot \Delta$ & $1 . / 194$ & 1 & $I T / r \Delta$ & واكنش هيجانى \\
\hline .11 .9 & $\%$ & $\mid r / \cdot r q$ & $\mathrm{IV} / \ldots \mathrm{F}$ & 1 & $r \cdot r / q q$. & رفتارهاى منفى \\
\hline.$/ \mu 1$. &.$/ \cdot 1$ & $\kappa \% / 1.1$ & F/ATr & 1 & rIT/IS. & دورى گزينى از حمايت جهره دلبستكى/ \\
\hline.$/ .94$ & $\% r$ & Q/QFV & $10 / 94 V$ & 1 & $1 \Delta \Delta / 94 \Delta$ & يرخاشخرى و فزون كنشى \\
\hline$\cdot / M M$ & $\% \cdot 1$ & rr/VOr & $1 \cdot 1099$ & 1 & $r q \cdot / q \cdot V$ & اضطراب و افسردگى \\
\hline.$/ 11 r$ & $\%$ & $\mid r / r a r$ & $\mid r / F M$ & 1 & $199 / \mathrm{VFF}$ & سازشنايافتكى اجتماعى \\
\hline.$/ 109$ & $\%$ & $1 N / \Delta \Delta \varphi$ & $1 . / 9 F A$ & 1 & $r \cdot r / 19 T$ & رفتارهاى ضداجتماعى \\
\hline ./Mr & $\% \cdot 1$ & Ir/GFY & N/9VY & 1 & $11 N / r \cdot F$ & اختلال نارسايى توجه \\
\hline
\end{tabular}

نمره كود كان كار كمتر از سـاير همسـالان است؛ در مؤلفهاى رفتارهاى منفى و دورى كزينى از حمـايست جهره دلبســــى / فرد مراقـب نمره كود كان كار بيشـتر از سـاير همسـالان بوده؛ و در مؤلفه واكنش هيجانى نمرات برابر داشـتهاند. حجم اندازه اثر نشـان ميدهد كه ه/Y ا درصـد از تغييرات تكامل انطباقى مثبت، 9/ ا ا درصد از تغييرات رفتارهاى منفى، و اس درصــد از تغييرات دورى كزينى از حمايت جهره دلبســـى / فرد مراقب ناشسى از تغييرات دو كروه كود كان كار و سـاير همسـالان اسـت. همجينين دو كروه از نظر خردهؤلفههاى مشــكلات هيجانى - رفتارى از ديد معلم نيز با هم تفاوت معنادار دارند زيرا آماره F براى يرخاشگرى و فزون كنشى (Q/9FV)، اضطر اب و افسردگى (YY/VDr)، سازش نايافتكى

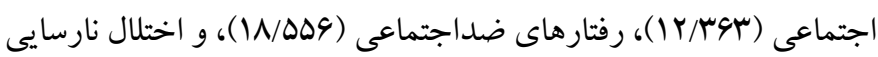

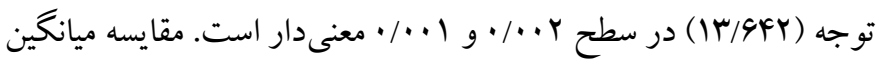

بـا توجه به جدول س، دو كروه از نظر خردهؤ لفههاى اميد به آينده با هم تفـاوت معنى دار دارنــ جر اكـه آمـاره F براى تفكر عاملى (I I (I)، و

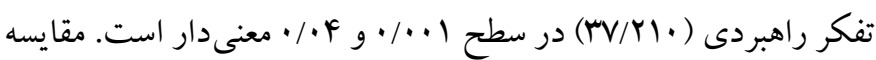
ميانخين نمرات كروهها نشــان مىدهد كه اين دو مؤلفه در كود كان كار كمتر از ساير همسالان است. از طرفى با توجه به حجم اندازه اثر، گروهها قـادرند س/ ا درصسـد از تغييرات تفكر عاملى و F// درصسـد از تغييرات تفكر راهبردى را تبيين كنند. جدول س نشـان مىدهد كه دو گروه از نظر

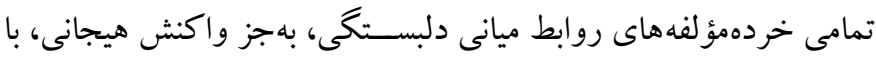
هم تفـاوت معنى دار دارنسـ زيرا آمـاره F براى تكـامـل انطبـاقى مثبـت

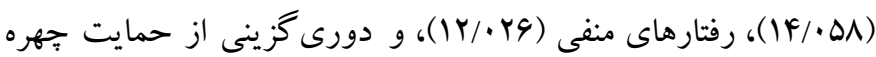

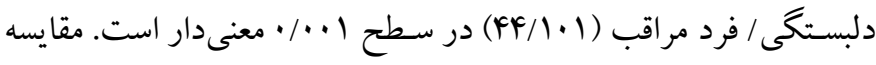
ميانگين نمرات كروهها نشــان مىدهد كه در مؤلفه تكامل انطباقى مثبت 
كردن امكان تحصـيل، روزنهاى به اميد به آينده به روى اين كودكان

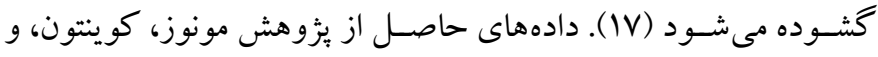

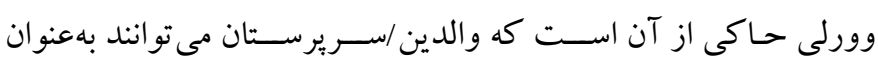
محر كك خـارجى ايجـاد اميـد درونى در نوجوانـان بـه آنها كمكك كنند،

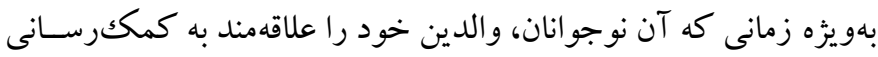

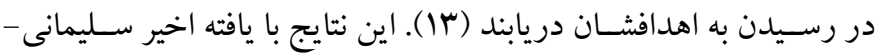

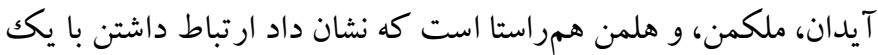

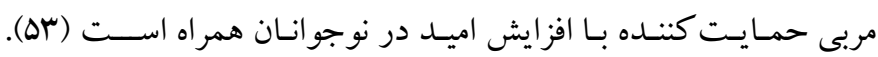

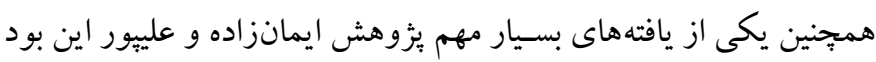

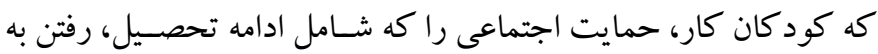
مدرسه، و بودن با دوستان مى شد، بهعنوان راهكارى براى غلبه بر ناميدى

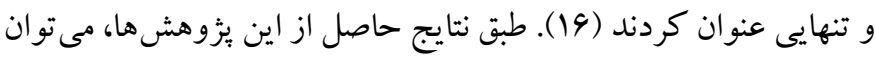

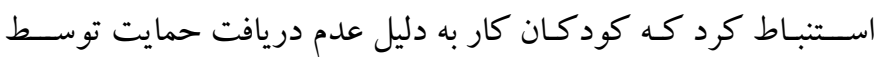
والدين يا سريرستان، ميزان اميد به آينده بايين ترى دارند و نسبت به به به آينده حس رهاشدكى و نااميدى مى كنند. همجنين نتايج يزوهش حاضسر نشـان داد كود كان كار نسبت به ساير

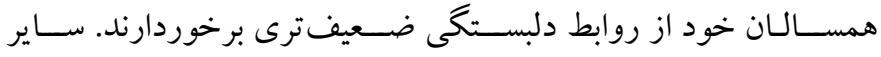

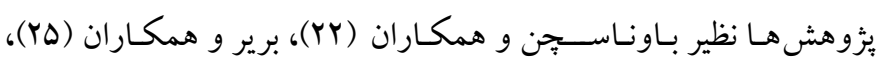

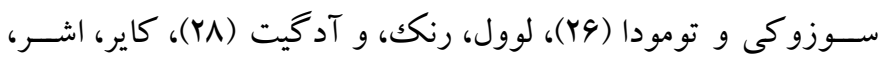

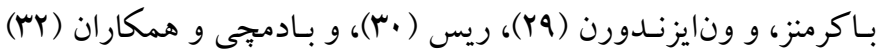

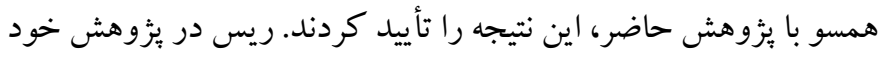

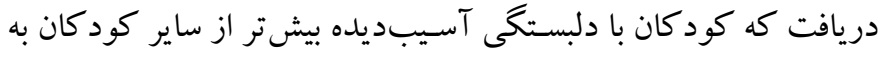

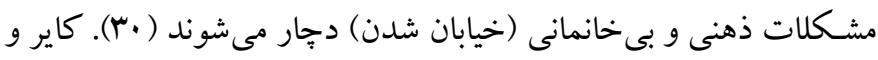

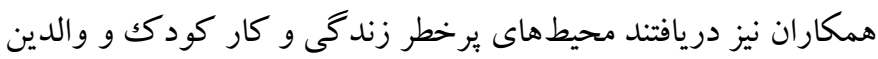

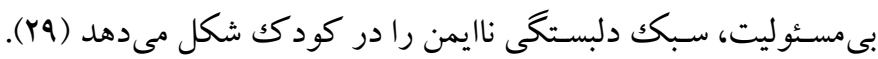

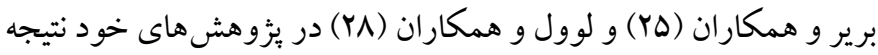

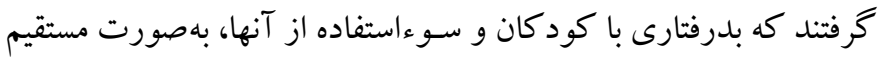

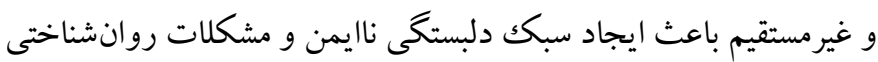

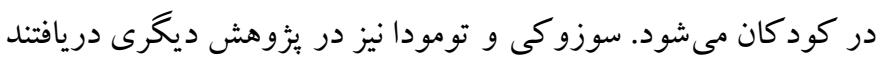

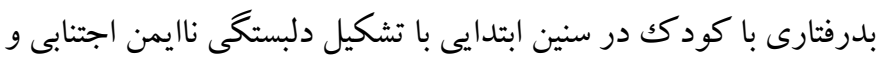
دوسو گر ا، رابطه مثبت و معنى دار دارد (Y4).
نمرات گروهها نشــان مىدهد كه تمامى مؤلفههاى مشـكلات هيجانى رفتارى از ديد معلم در كود كان كار بيشتر از ساير همسالان است. با توجه

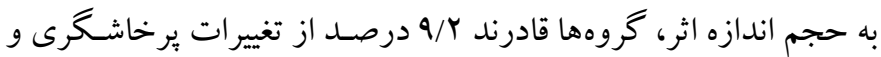

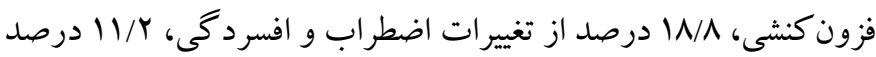

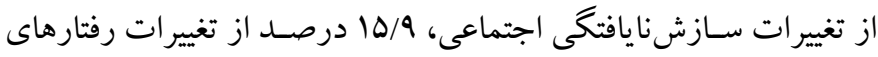

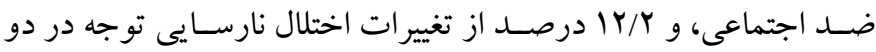
كروه كود كان كار و ساير همسالان را تبيين كنند.

\section{بحث و نتيجه Fيرى}

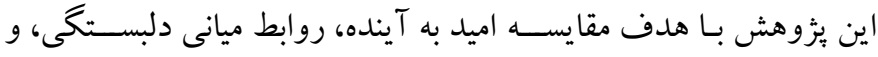
مشكلات هيجانى - رفتارى در كود كان كار با سـاير همسـالان انجام شد.

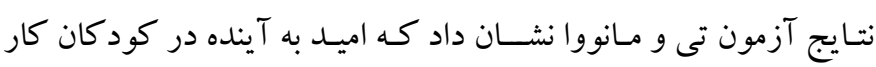

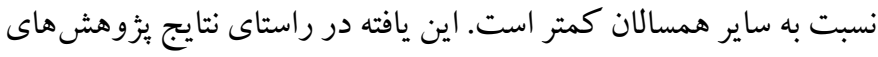

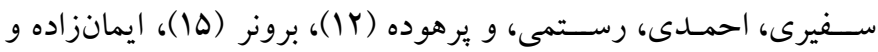

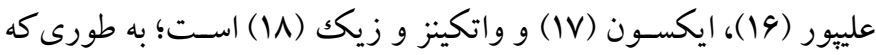
اين يزوهش ها نشان دادند كود كان كار از اميد به آينده كمترى نسبت به

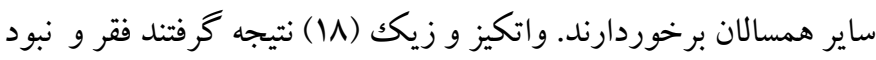

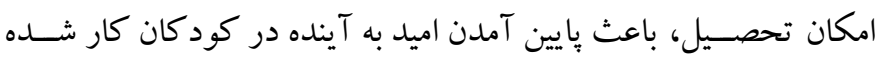

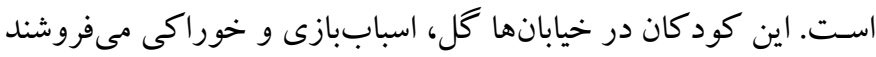
كه اين موضسوع به مسئلهاى عادى از طرف شهروندان تبديل شده است.

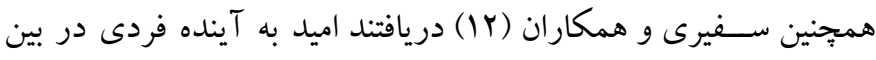
كود كان كار به دليل شـرايط خانوادگى نامناسـب كمتر از ساير كود كان

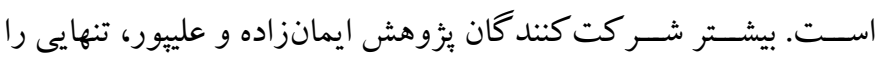

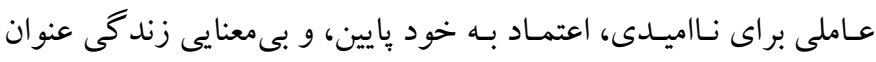

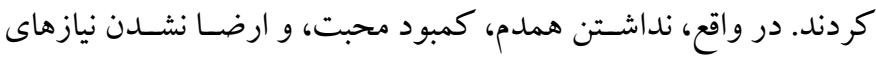
عاطفى در كود كان كار موجب احسـاس تنهايى و متعاقب آن ناميدى از آينده مى شود (19) - (19).

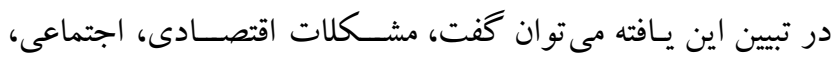
فيزيكى، و تحصيلى در زندگى كود كى، همجِنين بدرفتارى، سوء استفاده، خشـونت و كم توجهى نسـبت به كودكى، باعث بايين آمدن اميد در او

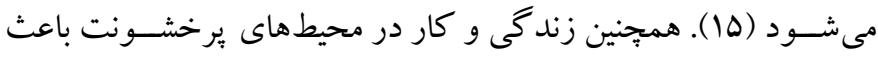

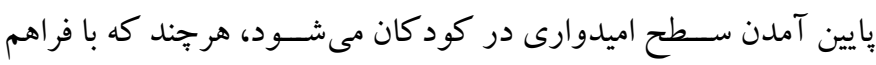


رفتارى بهطور قابلتوجهى در كودكان كار بيشتر از ساير كودكان است

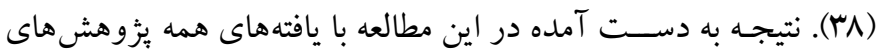
ذكر شده همخو انى دارد.

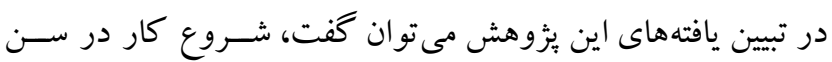

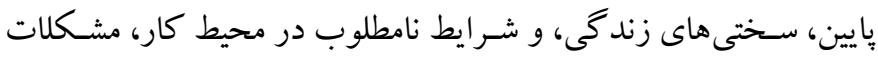

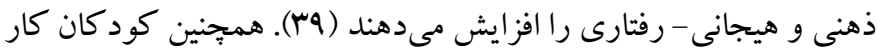

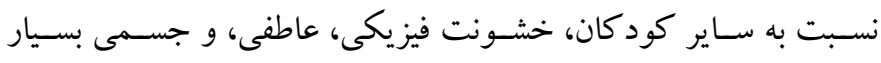

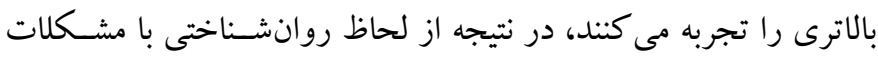

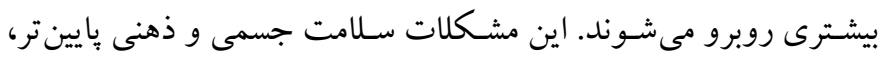
مشكلات رفتارى بيشتر و تحصسيلات ضسعيفتر را به دنبال دارد (F).

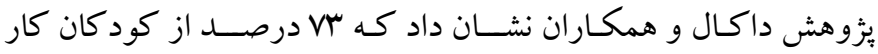
شـركت كننده در ئزوهش، در طول زندگى خود نوعى از سو استفاده را

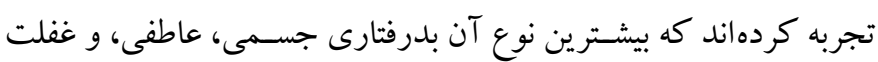
بود. همجينين علائم نشاندهنده تروما و اختلالات اضطر ابى نيز، بهويزه در قربانيان سـوءاسـتفاده در كودكى، مشــاهده شــــ (•F). طبق نتايج اين يُزوهش ها، و همجنين نتايج به دســت آمده از يُزوهش حاضــر مبنى بر ميزان اميد و دلبستخى ضعيف در كود كان كار، مى توان استنباط كرد كه

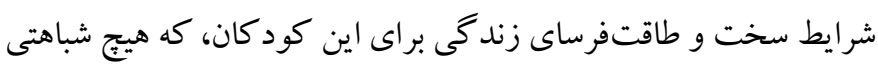

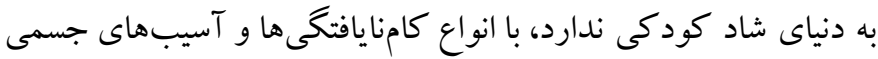
و روانى همراه بوده و همين امر، انواع مشكلات هيجانى و رفتارى را براى كود كان كار به همراه مى آورد.

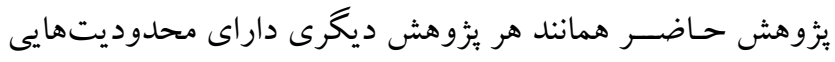

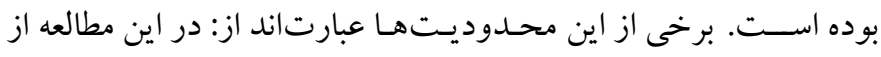

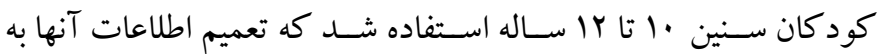
كروههاى سنى ديخر بايد با احتياط انجام شود؛ به علت محدود و كمياب بودن كودكك كار دختر، تفكيك جنسـيت و مقايسـهـ دو جنس در اين

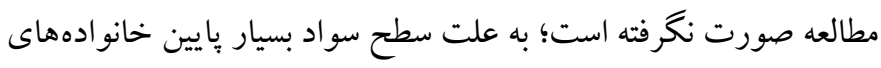

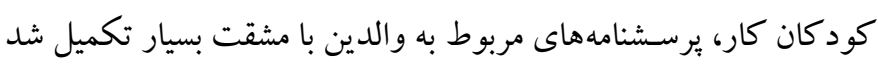

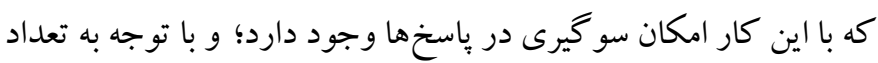

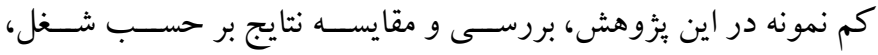

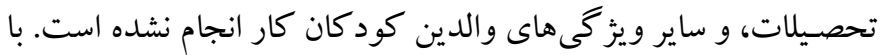

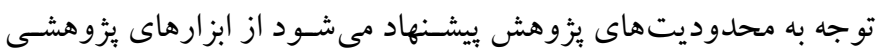

در تبيين اين يافته مىتوان كفت دلبستحى در كودكان ثابت نيست و مىتواند تحت شــرايط مختلف تغيير كند. در صـورت ياســخكو بودن

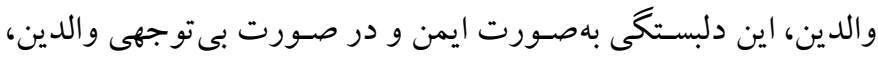

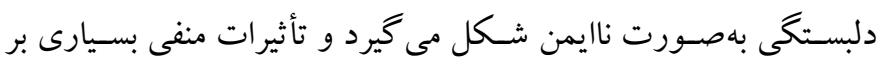

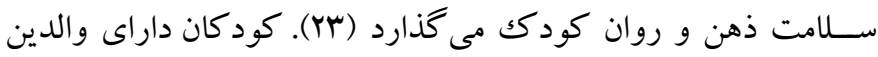
كمتوجه كه در رابطه خود امنيت، صسميميت، و همراهى كمترى نشـان

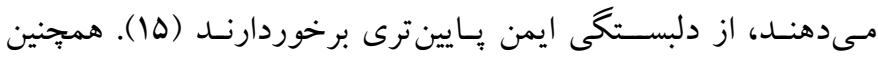

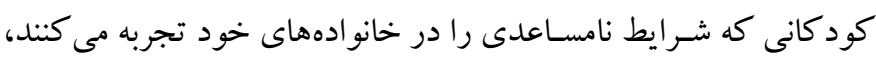

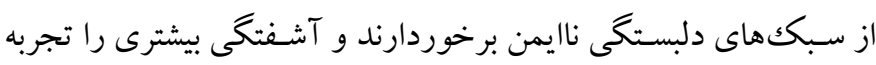

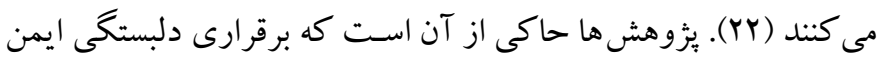

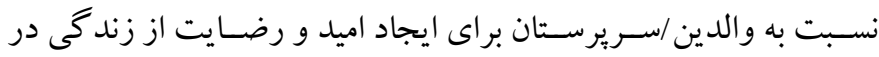

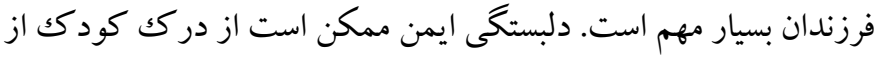

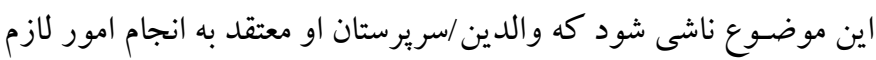
در جهت رسيدن فرزندان به اهداف خود هستند (سا). طبق اين دستاورد

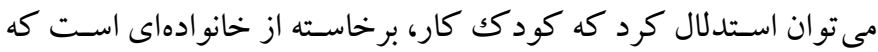
اطمينـان للازم را براى كمكك به كودك در رســيدن به اهداف و ايجاد

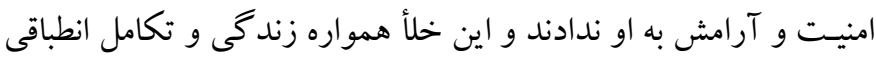
روابط دلبستكى در اين كود كان را تهلديد مى كند. به علاوه، اين بثزوهش نشان داد مشكلات هيجانى-رفتارى در كود كان

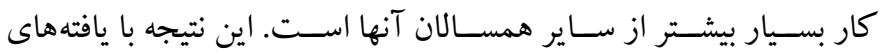

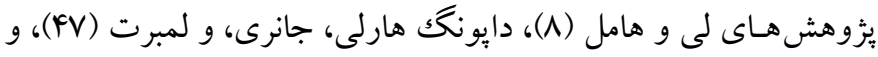

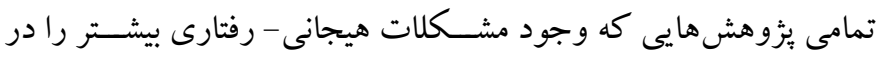

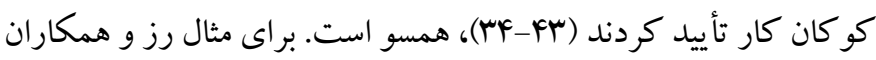

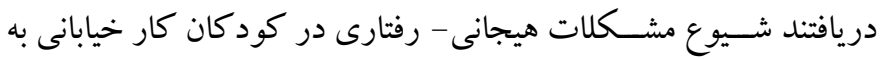

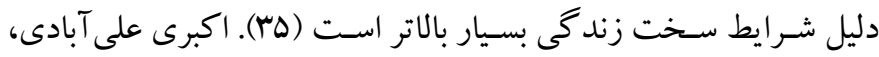

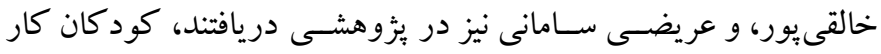

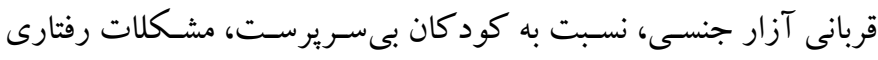

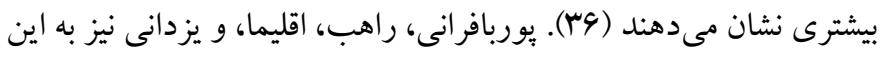

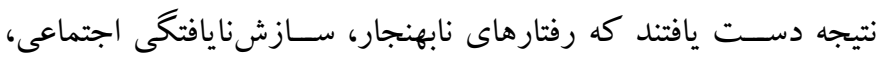
اختلال نارسـايى توجه در كود كان مراكز دولتى بهطور معنادارى بيشـتر

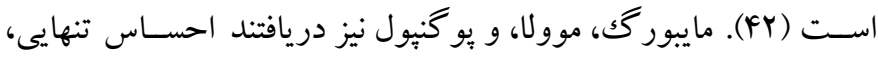
افسـردگى، عدم شـايستخى، مشكلات روانشناختى و مشكلات هيجانى - 
تشكر و قدردانى: يُزوهش حاضـر بركرفته از يا ياننامه كارشناسى ارشد خانم

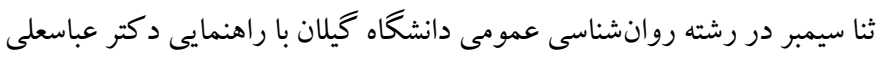

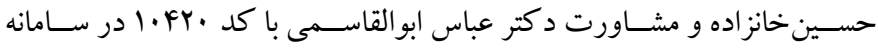

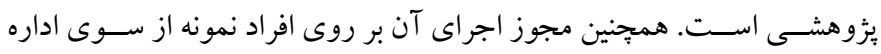

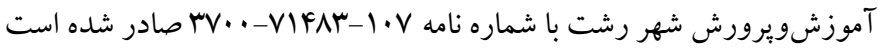
و در مؤسـســه حمايت از كود كان كار رشـت (به عنوان نهادى غيردولتى) و

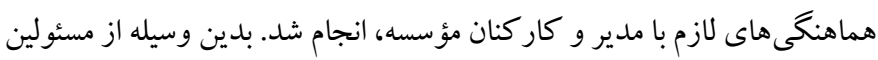

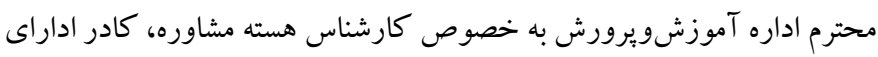

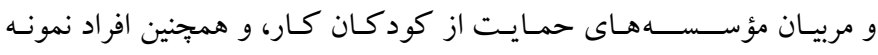
شر كت كننده در اين مطالعه، تشكر و قدردانى مى مودود. تضاد منافع: اين يزوهش بهطور مستقل انجام شده و نتايج آن به صورت كاملاً شفاف ار ائه شده است، در نتيجه هيج گونه تضاد منافعى وجو د نداشته است.
مختلفى علاوه بر برسشنامه، براى جمع آورى داده و از روشهاى ديخرى

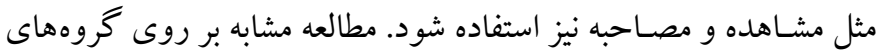

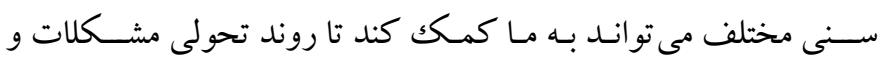
معضلان كودكان كار رارديابى كنيم. مقايسه كود كان كار بسر و دختر و همجنين مطالعه ويز گى هاى شـغلى و تحصيلات والدين كود كان كار نيز

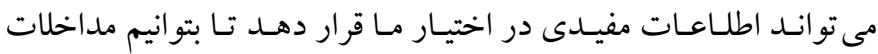

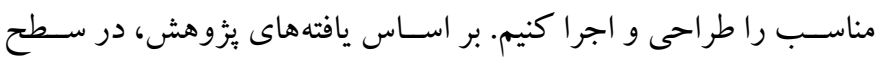
به كار بسته بيشـنهاد مى شود در مؤسسات حمايتى كو كان كار، با استفاده

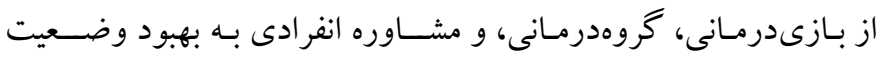
روانشناختى كود كان كار برداخته شود و همجنين نتايج اين بُزوهش در قالب بروشـور در اختيار مؤسســات حمايتى و آموزشسى كود كان كار و مدارس قرار گيرد تا با حمايت مالى و عاطفى از اين كود كان، شـيوههاى

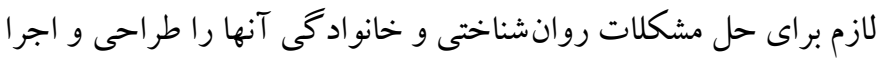




\section{References}

1. Pinzón-Rondón ÁM, Cifuentes LB, Zuluaga C, Botero JC, Pinzon-Caicedo M. Wealth, social protection programs, and child labor in colombia: a crosssectional study. Int J Health Serv. 2018; 48(3): 535548. [Link]

2. Vameghi M, Roshanfekr P, Ali D, Noroozi M, Madani $\mathrm{S}, \mathrm{McF}$ arland $\mathrm{W}$, et al. Population size estimates of street children in Iran: synthesis of multiple methods. J Urban Health. 2019; 96(4): 549-557. [Link]

3. Saffarzadeh J. Child labor. Second edition. Tehran: Parsketab; 2014, pp: 18-114. [Persian].

4. Mert K, Kadıoglu H. The reasons why children work on the streets: a sample from Turkey. Child Youth Serv Rev. 2014; 44: 171-180. [Link]

5. Kayiranga G, Mukashema I. Psychosocial factor of being street children in Rwanda. Procedia Soc Behav Sci. 2014; 140: 522-527. [Link]

6. Cummings PM. Child labor and household composition: determinants of child labor in Mexico. Asian Journal of Latin American Studies. 2016; 29(3): 29-54. [Link]

7. Radmard S, Beltekin N. A research on sociality of learning and success-istanbul street children case. Procedia Soc Behav Sci. 2014; 141: 1335-1338. [Link]

8. Le HT, Homel R. The impact of child labor on children's educational performance: Evidence from rural Vietnam. J Asian Econ. 2015; 36: 1-13. [Link]

9. Mobaraki H. The effectiveness of Narrative therapy on reducing clinical problems in child labor [Master Thesis]. [Tehran, Iran]: Faculty of Psychology and Educational Sciences, Kharazmi University; 2015, pp: 2-10. [Persian].

10. Admaw T, Ghosal S. Socio-economic determinants of child labor exploitation: the case study of Jimma Town, Ethiopia. International Journal of Economics \& Finance Research \& Applications. 2018; 2(1). [ISSN: 2581-4249 (online)]. [Link]

11. Chorny N de G, Raub A, Earle A, Heymann J. The state of child labor protections in 193 countries: are countries living up to their international commitments? Int J Sociol Soc Policy. 2019; 39(7/8): 609-626. [Link]

12. Safiri K, Ahmadi S, Rostami S, Parhoodeh F. The study of hopeful for the future of street working children (A case study of Tehran). Tehran, Iran: Second National Conference of Sociology and Social
Sciences, Narkish Information Institute; 2015, pp: 123. [Persian]. [Link]

13. Munoz RT, Quinton KA, Worley JA, Hellman CM. Locus of hope: external hope in parents/guardians as an antecedent of adolescents' internal hope and life satisfaction. Child Ind Res. 2019; 12(3): 1107-1124. [Link]

14. Alarcon GM, Bowling NA, Khazon S. Great expectations: a meta-analytic examination of optimism and hope. Pers Individ Dif. 2013; 54(7): 821-827. [Link]

15. Bruner C. ACE, place, race, and poverty: Building hope for children. Acad Pediatr. 2017; 17(7): 123-129. [Link]

16. Imanzadeh A, Alipour S. Tabriz's labor children's lived experience of loneliness: a phenomenological study. Quarterly of Social Studies and Research in Iran. 2019; 8(2): 279-304. [Persian]. [Link]

17. Akesson B. School as a place of violence and hope: Tensions of education for children and families in post-intifada Palestine. Int J Educ Dev. 2015; 41: 192199. [Link]

18. Watkins K, Zyck SA. Living on hope, hoping for education: the failed response to the Syrian refugee crisis. London: ODI; 2014, pp: 1-13. [Link]

19. Dixson DD, Keltner D, Worrell FC, Mello Z. The magic of hope: Hope mediates the relationship between socioeconomic status and academic achievement. J Educ Res. 2018; 111(4): 507-515. [Link]

20. Soleymani H, Bashash L, Latifian M. Psychometric properties of the kinship center attachment questionnaire (KCAQ) of latency-aged for children. Journal of Psychological Models and Methods. 2014; 4(16): 41-63. [Persian]. [Link]

21. Doinita NE, Maria ND. Attachment and parenting styles. Procedia Soc Behav Sci. 2015; 203:199-204. [Link]

22. Bovenschen I, Lang K, Zimmermann J, Förthner J, Nowacki K, Roland I, et al. Foster children's attachment behavior and representation: Influence of children's pre-placement experiences and foster caregiver's sensitivity. Child Abuse Negl. 2016; 51: 323-335. [Link]

23. Fearon RMP, Roisman GI. Attachment theory: progress and future directions. Curr Opin Psychol. 2017; 15: 131-136. [Link]

24. Stronach EP, Toth SL, Rogosch F, Oshri A, Manly JT, Cicchetti D. Child maltreatment, attachment 
security, and internal representations of mother and mother-child relationships. Child Maltreat. 2011; 16(2): 137-145. [Link]

25. Briere J, Runtz M, Eadie E, Bigras N, Godbout N. Disengaged parenting: Structural equation modeling with child abuse, insecure attachment, and adult symptomatology. Child Abuse Negl. 2017; 67: 260270. [Link]

26. Suzuki H, Tomoda A. Roles of attachment and selfesteem: impact of early life stress on depressive symptoms among Japanese institutionalized children. BMC psychiatry. 2015; 15: 8. [Link]

27. Widom CS, Czaja SJ, Kozakowski SS, Chauhan P. Does adult attachment style mediate the relationship between childhood maltreatment and mental and physical health outcomes? Child Abuse Negl. 2018; 76: 533-545. [Link]

28. Lowell A, Renk K, Adgate AH. The role of attachment in the relationship between child maltreatment and later emotional and behavioral functioning. Child Abuse Negl. 2014; 38(9): 14361449. [Link]

29. Cyr C, Euser EM, Bakermans-Kranenburg MJ, Van Ijzendoorn MH. Attachment security and disorganization in maltreating and high-risk families: A series of meta-analyses. Dev Psychopathol. 2010; 22(1): 87-108. [Link]

30. Rees C. Children's attachments. Paediatr Child Health. 2008; 18(5): 219-226. [Link]

31. Venta A, Shmueli-Goetz Y, Sharp C. Assessing attachment in adolescence: a psychometric study of the child attachment interview. Psychol Assess. 2014; 26(1): 238-255. [Link]

32. Bademci HÖ, Karadayı EF, de Zulueta F. Attachment intervention through peer-based interaction: Working with Istanbul's street boys in a university setting. Child Youth Serv Rev. 2015; 49: 20-31. [Link]

33. Khodam H, Modanlou MM, Ziaei T, Keshtkar AA. Behavioral disorders and related factors in school age children of Gorgan. Iranian Journal of Nursing Research. 2009; 4(14): 29-37. [Persian]. [Link]

34. Lokhmatkina NV, Feder G, Blake S, Morris R, Powers V, Lightman S. Longitudinal measurement of cortisol in association with mental health and experience of domestic violence and abuse: study protocol. BMC Psychiatry. 2013; 13(1): 188. [Link]

35. Roze M, Vandentorren S, Vuillermoz C, Chauvin P, Melchior M. Emotional and behavioral difficulties in children growing up homeless in Paris. Results of the
ENFAMS survey. Eur Psychiatry. 2016; 38: 51-60. [Link]

36. Akbari Aliabadi M, Khaleghipour S, Orayzie Samani $H$. The relationship between post-traumatic stress disorder and behavioral problems of sexually abused labor children compared to orphaned children. Journal of Pediatric Nursing. 2016; 3(1): 1-10. [Persian]. [Link]

37. Ban J, Oh I. Mediating effects of teacher and peer relationships between parental abuse/neglect and emotional/behavioral problems. Child Abuse Negl. 2016; 61: 35-42. [Link]

38. Myburgh C, Moolla A, Poggenpoel M. The lived experiences of children living on the streets of Hillbrow. Curationis. 2015; 38(1): 1274. [Link]

39. Avci D, Selcuk KT, Kaynak S. The magnitude and determinants of emotional-behavioral problems in working adolescents in Turkey. Arch Psychiatr Nurs. 2018; 32(1): 44-50. [Link]

40. Dhakal S, Niraula S, Sharma NP, Sthapit S, Bennett E, Vaswani A, et al. History of abuse and neglect and their associations with mental health in rescued child labourers in Nepal. Aust N Z J Psychiatry. 2019; 4867419853882. [Link]

41. Olsson J. Violence against children who have left home, lived on the street and been domestic workersA study of reintegrated children in Kagera Region, Tanzania. Child Youth Serv Rev. 2016; 69: 233-240. [Link]

42. Pourbaferani G, Raheb G, Eqlima M, Yazdani A. Comparison of behavioral disorders among children between the age of 7-12 living in public and private care centers in Tehran. Pajouhan Scientific Journal. 2013; 11(4): 18-23. [Persian]. [Link]

43. Ibrahim A, Abdalla SM, Jafer M, Abdelgadir J, de Vries N. Child labor and health: a systematic literature review of the impacts of child labor on child's health in low- and middle-income countries. J Public Health (Oxf). 2019; 41(1): 18-26. [Link]

44. Pur IG. Emotion regulation intervention for complex developmental trauma: working with street children. Procedia Soc Behav Sci. 2014; 159: 697-701. [Link]

45. Latif A, Ali S, Awan A, Kataria JR. Socio-economic and political determinants of child labor at brick kilns: A case study of district Jhang. South Asian Studies. 2016; 31(1): 161-174. [Link]

46. Yıldırım B, Beydili E, Görgülü M. The effects of education system on to the child labour: an evaluation 
from the social work perspective. Procedia Soc Behav Sci. 2015; 174: 518-522. [Link]

47. Duppong Hurley KL, January S-AA, Lambert MC. Using caregiver strain to predict participation in a peer-support intervention for parents of children with emotional or behavioral needs. J Emot Behav Disord. 2017; 25(3): 170-177. [Link]

48. Snyder CR, Hoza B, Pelham WE, Rapoff M, Ware L, Danovsky M, et al. The development and validation of the Children's Hope Scale. J Pediatr Psychol. 1997; 22(3): 399-421. [Link]

49. Aghakhani S, Bahari F. The effectiveness of nerve planning group-languages cognitive expectancy and quality of life for children with cancer. Iranian Journal of Psychiatry and Clinical Psychology. 2018; 24(3): 256-269. [Persian]. [Link]

50. Kappenberg ES, Halpern DF. Kinship center attachment questionnaire: development of a caregivercompleted attachment measure for children younger than 6 years. Educ Psychol Meas. 2006; 66(5): 852573. [Link]

51. Rutter M, Cox A, Tupling C, Berger M, Yule W. Attainment and adjustment in two geographical areas: I. The prevalence of psychiatric disorder. $\mathrm{Br} \mathrm{J}$ Psychiatry. 1975; 126(6): 493-509. [Link]

52. Ashori M, Dallalzadeh Bidgoli F. The effectiveness of play therapy based on cognitive-behavioral model: behavioral problems and social skills of pre-school children with attention deficit hyperactivity disorder. Archives of Rehabilitation. 2018; 19(2): 102-115. [Persian]. [Link]

53. Sulimani-Aidan Y, Melkman E, Hellman CM. Nurturing the hope of youth in care: the contribution of mentoring. Am J Orthopsychiatry. 2019; 89(2): 134-143. [Link] 